\title{
Audit Quality and Auditor Reputation: Evidence from Japan
}

\section{Citation}

Skinner, Douglas, and Suraj Srinivasan. "Audit Quality and Auditor Reputation: Evidence from Japan." Accounting Review 87, no. 5 (September 2012): 1737-1765.

\section{Published Version}

http://www.aaajournals.org/doi/abs/10.2308/accr-50198

\section{Permanent link}

http://nrs.harvard.edu/urn-3:HUL.InstRepos:29660921

\section{Terms of Use}

This article was downloaded from Harvard University's DASH repository, and is made available under the terms and conditions applicable to Open Access Policy Articles, as set forth at http:// nrs.harvard.edu/urn-3:HUL.InstRepos:dash.current.terms-of-use\#OAP

\section{Share Your Story}

The Harvard community has made this article openly available.

Please share how this access benefits you. Submit a story.

Accessibility 


\title{
Audit Quality and Auditor Reputation: Evidence from Japan
}

\author{
Douglas J. Skinner \\ John P. and Lillian A. Gould Professor of Accounting \\ University of Chicago, Booth School of Business \\ dskinner@chicagobooth.edu \\ Suraj Srinivasan \\ Associate Professor of Business Administration \\ Harvard Business School \\ ssrinivasan@hbs.edu
}

\section{Forthcoming: The Accounting Review, Volume 87, No.5 September 2012}

\begin{abstract}
:
We study events surrounding ChuoAoyama's failed audit of Kanebo, a large Japanese cosmetics company whose management engaged in a massive accounting fraud. ChuoAoyama was PwC's Japanese affiliate and one of Japan's largest audit firms. In May 2006, the Japanese Financial Services Agency (FSA) suspended ChuoAoyama for two months for its role in the Kanebo fraud. This unprecedented action followed a series of events that seriously damaged ChuoAoyama's reputation. We use these events to provide evidence on the importance of auditors' reputation for quality in a setting where litigation plays essentially no role. Around one quarter of ChuoAoyama's clients defected from the firm after its suspension, consistent with the importance of reputation. Larger firms and those with greater growth options were more likely to leave, also consistent with the reputation argument.
\end{abstract}

Key words: Audit quality, Auditor reputation, Japan.

Data Availability: All data in the paper are publicly available from the sources described in the text.

We are grateful to the Initiative on Global Markets at the University of Chicago Booth School of Business for financial support. We thank Joachim Gassen (AAA discussant), Kazuo Kato, Urooj Khan, Thomas Lys, Yosh Matsumoto, Masumi Nakashima, Tomomi Takada, Stephen Taylor, Joe Weber, Steve Kachelmeier and John Harry Evans (Editors), the two anonymous reviewers and workshop participants at the 2009 AAA Annual Meeting (New York City), Boston University, University of Edinburgh, Emory, Harvard Business School, London Business School, Manchester Business School, University of Melbourne, MIT, the 2009 NUS-Notre Dame CARE Conference, Ohio State University, the University of Washington, Yale School of Management Summer Accounting Conference, and Wharton for helpful comments on previous versions. We also thank Robert Eccles, Masako Egawa, Michael Krzus, Andrew Popham, Reiko Sato, Yoshiko Shibasaka, Hanado Yasuhito, Nabuo Sato, the staff of the Certified Public Accountants and Auditing Oversight Board at the Japan Financial Services Authority, and the staff of the Harvard Business School Japan Research Office for their valuable assistance in helping us understand the Japanese audit industry. Gang Huang, Kei Ikenishi, Kei Kondo, Allan Sumiyama, and Alice Thieu provided valuable research assistance. 


\section{INTRODUCTION}

High-quality external auditing is a central component of well-functioning capital markets. The accounting literature focuses on two principal forces that motivate auditors to deliver quality—a litigation/insurance incentive and a reputation incentive. Under the first motive, if auditors are legally liable for audit failures, they have an incentive to deliver high-quality audit to avoid the costs of litigation. The insurance role arises because investors prefer larger audit firms as these firms can better meet investors' legal claims thus providing investors' financial recourse against poor audit quality. Under the second motive, auditors have reputational incentives to avoid audit failures because audit quality is valuable to clients and so priced in the market for audit services. Under this view, clients defect to other auditors when an audit firm's reputation for quality deteriorates.

Empirically, it is difficult to separate the effects of litigation/insurance from those of reputation in markets such as the U.S. because the largest audit firms have both the largest litigation incentives and the strongest reputations. We study recent events in Japan where auditors' legal liability is essentially non-existent. Specifically, we study the case of ChuoAoyama, PricewaterhouseCoopers' (PwCs') former affiliate in Japan, which was implicated in a major accounting fraud at Kanebo, a large Japanese cosmetics company. This case provides a good setting for examining the importance of auditor reputation absent the confounding effects of litigation.

In May 2006, regulators in Japan took the unprecedented step of suspending ChuoAoyama's operations for two months as punishment for its role in the Kanebo fraud. Also in response to these events, and at about the same time, $\mathrm{PwC}$ adopted a "two-firm 
strategy” in Japan, under which it undertook to (i) address the audit quality problems at ChuoAoyama, which it rebranded Misuzu, and (ii) establish a new, smaller "high-quality" affiliate in Japan, which it named Aarata. A select group of Japanese clients that included Sony and Toyota, as well as large multinational clients with operations in Japan, moved to Aarata. The revelation in December 2006 of serious accounting irregularities at Nikko Cordial, another prominent ChuoAoyama client, ultimately caused Misuzu to be shut down.

Firms with a reputation for credible financial reporting are likely to change auditors when their audit quality is questioned to avoid the capital market consequences of potentially unreliable financial reporting (Hennes et al. 2011). However, these benefits must be balanced against the costs of switching auditors. First, firms face search costs in identifying and hiring a new audit firm. Second, incumbent auditors develop firmspecific knowledge and expertise about the client that is costly for a new auditor to acquire (DeAngelo 1981). ${ }^{1}$ Third, the supply of auditors is constrained in the short run, especially when many firms are looking for new auditors at the same time (Kohlbeck et al. 2008; Ramnath and Weber 2008), as is likely to be the case in our setting.

Prior research finds that local audit office effects are important in explaining auditor attributes such as client dependence (Reynolds and Francis 2000), industry expertise (Ferguson et al. 2003; Francis et al. 2005; Basioudis and Francis 2007), and audit quality in general (Francis and Yu 2009; Chaney and Philipich 2002; Nelson et al. 2008). This suggests that there is a local office effect on audit quality as well as an

\footnotetext{
${ }^{1}$ The "low balling" literature suggests that audit firms price the initial year of an audit engagement below cost to win the engagement with the expectation that the initial losses will be offset by higher fees in the future (Kanodia and Mukherji 1994). Therefore, the higher fees from an auditor change may not be immediately evident.
} 
overall audit firm effect. If audit quality problems are confined to a particular practice office, investors are less likely to be concerned about clients of other offices of the audit firm. Our setting provides an unusual instance in which audit quality was perceived to be low across an entire audit firm. As explained below, PwC effectively acknowledged that it could not consistently deliver quality in its Japanese operations by dividing ChuoAoyama into two firms, one of which (Aarata) it characterized as being of higher quality. ${ }^{2}$ The view that ChuoAoyama's problems were pervasive was reinforced by the regulator's decision to suspend its operations.

We find that roughly one-quarter of ChuoAoyama's clients dropped the firm as the extent of its audit quality problems became apparent but before it became clear that it would be wound down. ${ }^{3}$ Firms with a greater demand for audit quality—larger firms and those with greater growth options - were more likely to leave ChuoAoyama, consistent with our argument that switches were driven by concerns about audit quality.

It would be more difficult to attribute these switches to concerns about audit quality if client firms simply followed their existing audit partners to new audit firms after the suspension was announced. To investigate this, we compare the identity of the audit partners who sign the audit report before and after auditor changes. We first show that there is no overlap in the identity of audit partners who signed audit reports before and after switches for those ChuoAoyama clients that left the firm after the suspension

\footnotetext{
${ }^{2}$ Our characterization of Aarata as the higher quality firm follows the position of PwC's CEO Samuel DiPiazza, who said that "Aarata's limited size reflected the availability of staff who met the firm's performance standards." ("PwC to axe scandal-hit affiliate in Japan," Financial Times, February 20, 2007). Our interviews with former personnel of ChuoAoyama, auditors from other audit firms, company managers, academics in Japan, the senior staff of the Japan Institute of Certified Public Accountants, and the Auditing Oversight Board at the Japanese FSA confirm the view that Aarata was the higher-quality firm.

${ }^{3}$ Around a quarter of ChuoAoyama's clients moved to other auditors soon after the suspension was announced. We provide evidence and arguments later in the paper to show that this suspension did not make it likely that ChuoAoyama would subsequently be wound down, and that, as of the time of the suspension, most parties viewed the firm as being viable in the long run.
} 
was announced (i.e. those that switched in May, June, and July of 2006). In contrast, for those clients that switched auditors after the decision to close the firm in February 2007, there is a good deal of overlap in audit partners who signed audit reports before and after switches. These results are consistent with our interpretation that the switches in 2006 are driven by concerns about audit quality while those in 2007 are driven by the revelation that the firm would be wound down.

We also use an event study to investigate whether ChuoAoyama's clients suffered declines in equity value as information about the firm's lower audit quality was revealed. We find a statistically significant but small negative reaction to the set of events that collectively revealed the decline in quality. However, the event study likely lacks power because of the relatively long period over which these events unfold and the associated difficulty of isolating exactly when news about audit quality reached market participants.

Taken as a whole, our evidence supports the view that auditor quality and reputation are important in an economy where litigation does not provide auditors with incentives to deliver quality. ${ }^{4}$ Most prior literature finds at best mixed support for the importance of auditor reputation as a driver of audit quality (Lennox 1999; Willenborg 1999; Khurana and Raman 2004). Consistent with our findings, Weber et al. (2008) find evidence of client switching when fraud at ComROAD AG raised questions about audit quality at KPMG in Germany, where litigation costs are relatively small. Our findings are stronger than those in Weber et al., and exploit unusual features of the Japanese setting to further strengthen the interpretation that these results are driven by reputation.

\footnotetext{
${ }^{4}$ Murase et al. (2010) also examine auditor switching around the time of the ChuoAoyama events. Broadly similar to our findings, these authors find that clients with larger agency costs tended to switch to auditors unaffiliated with PwC while clients with larger switching costs tended not to change auditors.
} 
There are both similarities and differences between the events at ChuoAoyama and those surrounding the demise of Arthur Andersen in the U.S. The two sets of events are similar in that Andersen's ultimate demise, which resulted from its failed audit of Enron, was preceded by problems with its audits of Waste Management, Sunbeam, and the Baptist Foundation of Arizona. ${ }^{5}$ Most notably, Andersen's audits of Waste Management during the 1990s resulted in what was, at the time, an unprecedented settlement with the SEC, which included a \$7 million fine and a permanent injunction against further violations. It was this settlement that set the stage for the firm's subsequent criminal indictment in the Enron case.

Prior to the revelation of the fraud at Kanebo, ChuoAoyama had been implicated in accounting frauds at Yaohan Japan, Yamaichi Securities, and Ashikaga Bank. But it was its involvement in the fraud at Kanebo, like Andersen's involvement in the fraud at Waste Management, which resulted in the unprecedented action by regulators. As was the case with Andersen at Waste Management, the regulatory consequences of ChuoAoyama's involvement in the Kanebo fraud were unprecedented but did not threaten the existence of the firm. Consequently, the clients that switched from ChuoAoyama after the suspension was announced, unlike those that left Anderson following that firm's indictment, did not leave because of the imminent closure of the firm. Thus, it is more appropriate to analogize the events in the Kanebo/ChuoAoyama case to those at Waste Management/Andersen than to those of the Enron case. As indicated above, it was the subsequent revelation of accounting irregularities at Nikko Cordial that resulted in the closure of ChuoAoyama.

\footnotetext{
${ }^{5}$ As reported by Ball (2009, p. 292), Andersen settled lawsuits related to these audits for $\$ 27$ million in the case of Waste Management (including the SEC settlement), \$110 million in the case of Sunbeam, and \$217 million in the case of the Baptist Foundation of Arizona.
} 
The more significant difference between the two sets of events, however, is the absence of litigation in the Japanese setting. In the U.S., client losses attributable to Andersen's association with Waste Management could be due to reputational effects, legal consequences, or some combination thereof (as its legal costs mounted, the resources available to meet future legal claims at Andersen were diminished, reducing the insurance value of its audit services). ${ }^{6}$ Thus, the Japanese setting provides a substantially cleaner test of the market response to an auditor's loss of reputation.

Our setting is also different from that of Weber et al. (2008) in at least two respects. First, at the time of the events described here, litigation against auditors was largely unavailable to investors in the Japanese market. In contrast, auditors could be sued in Germany although damages were capped at relatively low amounts. Second, in our setting government regulators clearly signaled the systemic nature of the audit quality problems at ChuoAoyama by announcing a firm-wide suspension; the severity of the regulator's actions were, at the time, a shock to the Japanese financial community, which had been expecting a modest fine. In contrast, the revelations of audit quality problems at ComROAD AG in Germany were revealed gradually through the press.

There are a number of reasons that the suspension of ChuoAoyama in May 2006 did not raise questions about the firm's survival. First, there was no perception that the suspension was a "death penalty" for ChuoAoyama. The suspension was deliberately timed to begin on July 1 , after the conclusion of the annual reporting cycle including annual shareholder meetings in June. Second, the Japanese Institute of Certified Public Accountants discouraged poaching by competitor audit firms (Kyodo News, 2006), an

\footnotetext{
${ }^{6}$ Ball (2009) reports that Andersen began to lose clients in 2000 and the first part of 2001, before the problems at Enron came to light.
} 
action that would be unlikely if the firm's survival was in jeopardy. Third, there is no evidence that partners were leaving ChuoAoyama as clients defected between May and July 2006. If partners had feared that ChuoAoyama would shut down, we would expect to see departure of audit partners out of career concerns. Fourth, the suspension did not prevent clients from returning to ChuoAoyama when the suspension ended, and most did return. Fifth, the events we describe show that the actual end of Misuzu, the renamed ChuoAoyama, came after the revelation in December 2006 of serious accounting irregularities at another ChuoAoyama client, Nikko Cordial. Finally, our evidence shows that after the first set of client defections from May to July 2006, there was no meaningful client switching until March 2007, when an orderly transition of Misuzu clients to other audit firms began.

The next section provides more details about the Kanebo fraud, the role of ChuoAoyama, a discussion of prior literature, and empirical predictions. Section III describes our sample and provides empirical evidence. Section IV offers a summary and conclusions.

\section{THE DOWNFALL OF CHUOAOYAMA AND EMPIRICAL PREDICTIONS The Kanebo Fraud and the Downfall of ChuoAoyama}

In 2004 Kanebo, a longtime ChuoAoyama client, revealed a massive accounting fraud and began an internal investigation that resulted in Kanebo dropping ChuoAoyama as its auditor. Appendix A lists key events in the case. In April 2005, Kanebo revealed that the accounting fraud amounted to an overstatement of income by around 200 billion yen ( $\$ 1.9$ billion) for the fiscal years 1999-2003. After correction, the restated financial 
statements showed a cumulative loss during that time period of 207 billion yen. ${ }^{7}$ While Kanebo was the largest corporate fraud in Japanese history (Hosono 2008), ChuoAoyama had previously been implicated in other accounting frauds, including Yaohan Japan Corp. (1997), Yamaichi Securities (1999), and Ashikaga Bank (2000). In July 2005 three former Kanebo executives were arrested and government prosecutors searched ChuoAoyama's offices. Over the next few months, government prosecutors indicted three ChuoAoyama auditors and ChuoAoyama’s board resigned.

PwC took a number of steps to preserve its reputation in the wake of these events. First, late in 2005, Samuel DiPiazza, worldwide head of PwC, traveled to Japan to meet with Japanese regulators, ChuoAoyama executives, and management of important clients, largely to assure them of PwC's commitment to correcting the problems at ChuoAoyama. Second, early in 2006 PwC sent high-level audit personnel from the U.S. and U.K. to take corrective action at ChuoAoyama. In addition to making operational and training improvements at ChuoAoyama, PwC considered forming a new, smaller audit firm that would operate independently of ChuoAoyama. PwC identified four of the firm's Japanese staff, all former Aoyama (Price Waterhouse) partners, as candidates to head the new firm. ${ }^{8}$ However, the Japanese leadership of ChuoAoyama resisted this change, arguing that such a drastic step was unnecessary.

During the trial of the Kanebo executives, the accused ChuoAoyama auditors admitted their complicity in the fraud, a revelation that came as a surprise to others in the

\footnotetext{
${ }^{7}$ Japanese GAAP first required consolidated financial reporting in the late 1990s. The Kanebo fraud involved the failure to include 14 poorly performing subsidiaries in its consolidated financial statements (Hosono 2008; Hawkins et al. 2010).

${ }^{8}$ ChuoAoyama was formed in April 2000 from a merger between Chuo Audit Corp. (the Coopers \& Lybrand affiliate) and Aoyama (the Price Waterhouse affiliate). Chuo was responsible for the three audit failures mentioned in the text. At the time of the merger, Chuo, which contributed 310 partners to the merged firm, was much larger than Aoyama, which contributed 37 partners.
} 
firm. In late March 2006 the former ChuoAoyama auditors themselves went on trial and pleaded guilty to the charges. These events made it more difficult for ChuoAoyama leadership to argue that their initial reforms were sufficient. PwC then decided to proceed with its "two-firm strategy" of forming a new, smaller firm, to be known as PwC Aarata, and rebranding the rest of ChuoAoyama as Misuzu Audit Corp. When PwC announced this strategy in May 2006, it indicated that Aarata would audit PwC's international clients in Japan and in return PwC would audit the international operations of Aarata’s Japanese clients. Most of ChuoAoyama's clients and staff went to Misuzu, which was essentially a reconstituted ChuoAoyama, while a smaller group of clients, and arguably those of most strategic importance to $\mathrm{PwC}$ internationally (Sony and Toyota being the most prominent examples), went to Aarata. ${ }^{9}$ Consistent with its higher quality status, Aarata was not subject to sanctions and was allowed to conduct business during the ChuoAoyama suspension period.

On May 10, 2006, the Japanese Financial Services Agency (FSA) ordered a twomonth suspension of the audit operations of ChuoAoyama beginning July $1,2006 .{ }^{10}$ With some exceptions, the rule effectively forced ChuoAoyama to suspend business for two months. ChuoAoyama's clients took one of three actions as a result. First, some firms appointed an interim auditor for the period of the suspension and returned to ChuoAoyama when it resumed business as Misuzu. Second, other firms returned to Misuzu after the suspension without appointing an interim auditor. Third, some firms

\footnotetext{
${ }^{9}$ We provide evidence below that most former Aoyama clients still audited by ChuoAoyama in fiscal year 2006 went to Aarata but only a small fraction of former Chuo clients went to this firm. This is consistent with the suggestion that Aarata was a reconstituted version of Aoyama, the original Price Waterhouse affiliate.

${ }^{10}$ In the only previous business suspension order against an audit firm in Japan, Mizuho Audit Corporation, a smaller audit firm, was suspended for one year on October 15, 2002.
} 
chose a different auditor and did not return to Misuzu, including around 50 firms that switched to Aarata. While companies in Japan are required to have an external auditor at all times, the FSA stated following the suspension order that "realistically speaking we are not sure whether all companies will be able to name a temporary auditor" ("PwC's Japan arm suspended”, Financial Times, May 11, 2006), referring to constraints on the availability of alternative auditors. This suggests that the FSA did not enforce the rule and there existed some level of regulatory forbearance on this issue. ${ }^{11}$

In December 2006 allegations of serious accounting irregularities at Nikko Cordial, another ChuoAoyama client, came to light. To preempt further regulatory action and reputational damage, PwC announced on February 20, 2007 that they would terminate Misuzu. PwC proposed to transfer all staff and clients to other audit firms after fiscal 2006 audits were completed in the spring of $2007 .^{12}$

\section{Previous Literature and Empirical Predictions}

Previous literature provides two types of evidence on auditor reputation. Both lines of research rely on the premise that when reputation is important in the audit market, observable declines in audit firm quality will lead to adverse consequences for its clients.

\footnotetext{
${ }^{11}$ Under the Japanese Financial Instruments and Exchange Act, an annual securities report must be submitted within three months of the end of that fiscal year. ChuoAoyama's suspension was timed to start from July 1 as most Japanese companies end the fiscal year on March 31 and complete their annual reports and hold meetings by the end of June. Under the Companies Act in Japan, a company is required to have an auditor at all times. Thus ChuoAoyama's clients needed to find interim auditors during the two months of the suspension period.

${ }^{12}$ There is some ambiguity about who initiated the closure of Misuzu. Some articles, including those that cite Samuel Di Piazza, then CEO of PwC, characterize this as a decision taken by PwC internationally ("PwC to axe scandal-hit affiliate in Japan," Financial Times, February 20, 2007). Other sources indicate that the local management of Misuzu made the decision in order to preempt its loss of clients as a result of the cumulative effect of the accounting scandals (see "Former ChuoAoyama forced to call it quits," Asahi Shimbun, February 21, 2007; “Auditor Misuzu jettisons CPAs, corporate work,” Japan Times, February 21, 2007). These actions enabled the firm to avoid "losing face" by having to close involuntarily and lay off staff. Thus, soon after the new fraud came to light, Misuzu cooperated with Tohmatsu, ShinNihon, and AZSA (the remaining Big audit firms) to transfer its audit personnel and clients to those other firms. There is little doubt, however, about the basic cause and effect- the revelation of the accounting fraud at Nikko Cordial quickly resulted in the demise of Misuzu.
} 
One line of research examines auditor switching around events that signal a decline in an audit firm's quality. Lennox (1999) analyzes audit failures in the U.K. from 1987 to 1994 and finds that larger auditors are more likely to be sued, consistent with the liability argument, but that clients generally do not drop auditors following audit failures as the reputation argument would predict. Shu (2000) finds that, consistent with the litigation argument, auditor resignations reflect increases in client litigation risk as well as changes in audit firm characteristics. Also consistent with the litigation argument, she finds that clients tend to move to smaller audit firms after a large auditor resigns, and that there is a significant negative stock price reaction to these events.

Barton (2005) examines auditor switches after the market learned about the scope of Andersen's audit failure at Enron. However, the events at Enron and the associated demise of Andersen occurred over a short period of time, making it difficult to distinguish whether the auditor switches reflected primarily reputation concerns versus being forced by the Andersen closure. Barton finds that 95 percent of the switches away from Andersen occurred after Andersen was indicted in March 2002.

A second line of research examines the stock price reaction to events that change market perceptions of the quality of services provided by a given audit firm. Menon and Williams (1994) and Baber et al. (1995) examine the reaction of client stock prices to the bankruptcy of Laventhol and Horwath, at the time the seventh largest audit firm in the U.S. Both studies report a significant negative reaction to the announcement, consistent with both the insurance and reputational roles for auditors. Chaney and Philipich (2002) examine the stock price reaction for clients of Andersen when it revealed document shredding related to the Enron audit. They find a significantly negative reaction, which 
they attribute to Andersen's loss of reputation, although Nelson et al. (2008) contest this interpretation because of confounding news on the event dates. Cahan et al. (2009) investigate the stock price reaction to Enron-related events for the non-U.S. clients of Andersen and find evidence of significantly negative reactions, which supports the importance of reputation. Krishnamurthy et al. (2006) also provide evidence that Andersen clients suffered negative market returns around the time of Enron-related events and relate these returns to cross-sectional measures of audit quality.

To more clearly distinguish the insurance and reputational explanations, Weber et al. (2008) examine an audit failure in Germany, where auditors' legal liability is limited, reducing the viability of the insurance rationale. Consistent with the reputation argument, they find that the stock prices of KPMG clients declined at the time of events that revealed KPMG's involvement in an audit failure at ComROAD. These authors also find that an unusually large number of clients dropped KPMG in 2002, the year of the ComROAD scandal.

The events at ChuoAoyama provide a powerful setting for assessing the importance of auditor reputation, allowing us to extend the findings of Weber et al. (2008). First, litigation against auditors is virtually non-existent in Japan. This means that there is effectively no insurance role for auditing in Japan. ${ }^{13}$ Second, the FSA's decision to suspend ChuoAoyama was unexpected and largely unprecedented. ${ }^{14}$ Third, these events unfolded over a relatively extended period, from the first indication of accounting

\footnotetext{
${ }^{13}$ This is clearly true for Japanese firms that are not listed outside Japan but less true for Japanese firms cross-listed in the U.S. and subject to U.S. securities laws. Litigation in Japan, including securities litigation, is much less prevalent than in western countries although this is gradually changing (Ginsburg and Hoetker 2006). In spite of an increase in litigation rates since around 1990, expected litigation costs remain lower in Japan than in the U.S. West (2001) provides evidence that the number of shareholder derivative lawsuits in Japan have increased but that settlements are unusual and stockholders lose most of these cases.

${ }^{14}$ Consistent with previous cases, regulators had announced that they would impose some type of sanction against ChuoAoyama. However, most previous sanctions had been relatively inconsequential.
} 
problems at Kanebo in the spring of 2004 to early 2007, when Misuzu ceased operations. The separation in time between May 2006, when the FSA announced its suspension and PwC decided to split the firm, and its eventual demise in February 2007, allows us to clearly identify the effects of auditor reputation and separate them from the effects of the firm's closure. Fourth, we have direct evidence that reputation played an important role in these events-PwC intervened quickly and forcefully when it became clear that ChuoAoyama's problems were going to attract the attention of investors and regulators in a significant way. It seems clear that the management of PwC was prepared to sacrifice a large part of its Japanese business to preserve its reputation. ${ }^{15}$

The suspension of ChuoAoyama and PwC's decision to split the firm into two parts signaled to clients and investors that Aarata was of higher quality than ChuoAoyama. Such an unambiguous, firm-wide audit quality signal has not been available in prior research settings. Moreover, by suspending ChuoAoyama, Japanese regulators (perhaps inadvertently) reduced switching costs for its clients. Because firms in Japan are required to have an external auditor at all times, firms were forced to find another audit firm for the suspension period. While client firms could return to ChuoAoyama (Misuzu) when it resumed business, the appointment of interim auditors made it easier for ChuoAoyama's clients to review their contracts given that they had already incurred some of the switching costs.

Finally, data available to us in Japan permits more detailed analysis of the auditor switching decision than in Weber et al. (2008). First, Weber et al. cannot distinguish

\footnotetext{
${ }^{15}$ Consider the following quote from Samuel DiPiazza, then CEO of PwC: "In PwC we're not perfect, but I think we have sent the message. In Japan we shut that firm down. We gave up a major amount of businesses, but we did it because we felt that the most important [asset] was our quality in that market to be at the highest level. We feel that we have that today: even if it's smaller, it's a better quality" ("Big consultancies should focus more on quality, transparency,” Czech Business Monthly, September 17, 2007).
} 
client switching due to supply-side effects, such as KPMG reducing its exposure to risky clients, from demand-side effects in which clients switch to maintain a reputation for financial reporting quality. Weber et al. find that smaller firms and those that recently completed IPOs are more likely to switch auditors, but both of these characteristics are also consistent with KPMG attempting to avoid riskier clients after the scandal. In contrast, the spin-off of Aarata meant that ChuoAoyama was already facing the loss of clients and so unlikely to reject other clients. ${ }^{16}$ Second, we use the date of auditor changes to isolate changes that occurred after the suspension in May 2006 but before the Nikko Cordial fraud came to light in December of that year. Thus, we can more confidently associate client switching with the reputational impact of the events at ChuoAoyama. Finally, in Japan audit partners sign audit reports in their own names as well as those of their audit firms. This allows us to examine the extent to which clients follow their audit teams from one audit firm to another, which is an alternative explanation for switching that is less consistent with improving audit quality. While the audit partner names are also disclosed in Germany, Weber et al. (2008) do not use that information.

To assess the extent to which evidence from these events supports the importance of auditor reputation, we first analyze auditor changes during the period over which these events unfold. If auditor reputation is important, we expect client firms to switch auditors when the incumbents are revealed to be of low quality. Second, we analyze the market reaction to the events that led to the FSA's suspension of ChuoAoyama. If reputation is

\footnotetext{
${ }^{16}$ Our understanding is that when clients started leaving, ChuoAoyama/Misuzu pursued a market share maximization approach that was also consistent with the desire to retain existing partners and staff.
} 
important and we have identified these events correctly, the costs of lower audit quality should be observable as declines in the stock prices of ChuoAoyama's clients.

\section{EMPIRICAL ANALYSIS}

\section{Sample and Descriptive Statistics}

We sample all firms listed on the First and Second Sections of the Tokyo Stock Exchange (TSE) in February 2008, a total of 2,199 firms. To mitigate possible survivor bias, we add firms that delisted during or after January 2004, increasing the sample by about 200 firms. We identify sample firms' auditors from Japanese securities filings (yukoshoken hukoksho) from fiscal 2001 through fiscal 2007. ${ }^{17}$

\section{Analysis of Market Share}

We report the number of publicly listed firms audited by Big and non-Big auditors in Panel A of Table 1; ${ }^{18}$ from fiscal years 2001 through 2007 the annual average is about 2,150 firms. ${ }^{19}$ Panel A statistics show that there is a high degree of audit market concentration in Japan. The Big auditors cover between 81 and 84 percent of the market in our sample period when measured by the number of clients and 92 to 95 percent when weighted by client firm size. The Big audit firms in Japan at the time of the events described were ChuoAoyama/Misuzu/Aarata (PwC), Asahi (Andersen), Azsa (KPMG), ShinNihon (Ernst \& Young), and Tohmatsu (Deloitte).

\section{[Place Table 1 Here]}

\footnotetext{
${ }^{17}$ In Japan most companies end the fiscal year on March 31. We use the Compustat convention to label firm/years; for example, we refer to the fiscal year ended March 31, 2007 as fiscal 2006 or F2006.

${ }^{18}$ We use the terminology "Big" auditors to refer to local affiliates of the large international audit networks. These are ChuoAoyama/Misuzu/Aarata (PwC), Asahi (Arthur Andersen), AZSA (KPMG), ShinNihon (Ernst \& Young), and Tohmatsu (Deloitte). Non-Big are all other audit firms.

${ }^{19}$ We limit the sample in this table to observations with non-missing market capitalization data to make the sample more comparable to that used in subsequent empirical analyses. The number of observations in later tables may be lower due to the availability of data on all the control variables.
} 
For each of the Big audit firms, Panel B of Table 1 reports the time series distribution of the number of client firms while Panel C provides market share based on the client firm market capitalization. Panel B shows that in F2001 and F2002 four Big audit firms dominate the market. There is a shift in F2003, when Asahi (Andersen) combined with Azsa and retained the Azsa name. The numbers for F2004 are similar.

The problems at Kanebo and ChuoAoyama came to light in 2004. The problems became more serious in the middle of 2005, when government prosecutors arrested executives from Kanebo and auditors from ChuoAoyama and searched ChuoAoyama's offices. This means that any switching away from ChuoAoyama could have begun in F2005 (ending March 30, 2006). However, the number of ChuoAoyama clients stays essentially unchanged in F2005, as seen in Panel B where ChuoAoyama audited 471 clients in F2004 and 469 clients in F2005.

The suspension of ChuoAoyama and the split into Misuzu and Aarata was announced in May 2006, allowing companies to decide whether to switch auditors for F2006 before their annual stockholder meetings in June 2006. Panel B of Table 1 shows that in F2006 the total of ChuoAoyama (7 clients), Misuzu (303 clients) and Aarata (52 clients) is 107 less than the 469 clients audited by ChuoAoyama in F2005, implying that a significant number of firms moved away from ChuoAoyama as these events unfolded. The other Big audit firms were the primary beneficiaries. Because the decision to close Misuzu did not occur until February 2007, it seems reasonable to interpret the F2006 audit changes as a response to concerns about audit quality rather than changes forced by the termination of Misuzu. 
The F2006 to F2007 loss of clients for Misuzu are more likely forced by its closure and therefore more difficult to attribute to reputational concerns. The closure was announced in late February 2007, and all but 15 of the 303 Misuzu clients in F2006 had left by F2007. ${ }^{20}$ Misuzu terminated operations following completion of audits for F2007. To summarize, these data show that the number of publicly listed ChuoAoyama clients was essentially unchanged in F2005 but declined significantly from 469 in F2005 to 362 (i.e., 7 in ChuoAoyama, 303 in Misuzu, and 52 in Aarata) in F2006 and even further to 75 (15 in Misuzu and 60 in Aarata) in F2007. We attribute the movement away from ChuoAoyama from F2005 to F2006 to concerns about audit quality, supporting the importance of reputation effects. ${ }^{21}$

By F2007, when the auditor changes forced by the termination of Misuzu had largely occurred, the market share of the remaining Big auditors was 81.2 percent (Panel A of Table 1), only marginally below the level of 83.8 percent in F2005. The sizeweighted shares reported in Panel C of Table 1 show that the market share of Big auditors is even more pronounced. Non-Big auditors capture their highest share of the market in F2007 at only 7.6 percent.

Panel D of Table 1 reports the auditor turnover rates in Japan for the sample time period. In all six years of the sample period auditor turnover rate for the Big auditors

\footnotetext{
${ }^{20}$ The fifteen client firms remaining with Misuzu in fiscal year 2007 are firms with fiscal years that end after March 31 for which the fiscal 2007 year-end concludes in calendar 2007 so that Misuzu could complete the fiscal 2007 audit before it closed on July 31 of that year. Our subsequent Table 4 Panel B provides statistics on the eventual auditor in F2007. Of the 303 firms audited by Misuzu, only 49 firms move to Non Big audit firms. All other clients move to a Big Auditor. We are unable to find the subsequent auditor for 50 firms because we are unable to find the relevant filings.

${ }^{21}$ To provide qualitative evidence on the reasons provided by clients for leaving ChuoAoyama, we examined the auditor change disclosure filed by these companies after the suspension announcement. The filing document known as konin kaikeishi tou no idou (Change (transfer) of certified public accountant) is obtained from the TSE Timely Disclosure Network (TDnet). In a random sample of 40 companies that we examined, companies offered either no reason for the change or boilerplate language that the change was due to the suspension. We concluded that this disclosure is not useful for our analysis.
} 
excluding ChuoAoyama and Misuzu in Japan is low, ranging from 0.6 percent in F2004 to 2.5 percent in F2003, with most years around 1 percent. The turnover rate for non-Big auditors is higher ranging from 3.1 to 10.7 percent. The turnover rate for ChuoAoyama through fiscal 2005 are similar to those of the other Big audit firms. However, turnover for ChuoAoyama increases substantially, to 23.7 percent in fiscal 2006, consistent with Panels B and C. This suggests there is a shift away from ChuoAoyama as its problems became more evident. Turnover rate for ChuoAoyama/Misuzu in F2007 is much higher again, at 92.5 percent, but this is due to the winding up of the firm.

The decision to terminate Misuzu followed the Nikko Cordial scandal that was first revealed in December 2006, seven months after the suspension order against ChuoAoyama in May 2006. There is no indication that the closure of Misuzu was anticipated before the Nikko Cordial became public. Supporting this, there are no client departures from Misuzu between the end of the suspension on September 1, 2006 and December 17, 2006 when the Nikko Cordial scandal became public. Table 1 Panel E provides further information on the timing of auditor switches. We are able to find the exact auditor change announcement for 453 of the 469 ChuoAoyama clients identified in Table 1 Panel B. Table 1 Panel E shows that client switching after the suspension occurs in May, June, and July of 2006. The only departure during December occurs late in the month, after the Nikko Cordial announcement. The next major batch of departures occurs in May 2007, after Misuzu announced its impending closure in February 2007. This suggests that the earlier departures from ChuoAoyama were not due to fears that the firm would cease operations after the suspension announcement in May 2006. 
To test whether the F2006 auditor switches away from ChuoAoyama are unusually frequent, we estimate a logit model of factors that explain auditor changes. The control variables are drawn from previous research on auditor switches and include firm size (log of total assets), growth (percentage change in total assets), leverage, change in leverage, profitability (ROA), a loss dummy, U.S. listing, keiretsu inclination, auditor industry expertise, earnings quality as measured by accruals, whether the firm completed a M\&A transaction in the preceding two years, and industry fixed effects. ${ }^{22}$ We provide details of data sources and variable definitions in Appendix B. The keiretsu inclination variable measures whether and to what extent these firms are part of the large corporate groups common in Japan (e.g., Aoki et al. 1994; Hoshi and Kashyap 2001).

We include dummy variables for whether the client is a ChuoAoyama client $(C A)$, for fiscal year 2006 (F2006), and for the interaction of these two dummies (CA_F2006). The interaction variable is our primary interest because it measures the extent to which client firms switch away from ChuoAoyama in fiscal 2006, the period in which we argue that auditor reputation drives switching. ${ }^{23}$

We report the results of these regressions in Table 2. There are fewer observations in the multivariate tests in Table 2 than in Table 1 because we require data on all of the control variables. ${ }^{24}$ In Column (1) estimation we do not treat a move from ChuoAoyama

\footnotetext{
${ }^{22}$ For example, see DeFond 1992; Francis and Wilson 1988; Barton 2005; Weber et al. 2008; and Landsman et al. 2009.

${ }^{23}$ Because the conventional logit coefficients on interaction variables do not provide a statistical test of whether the economic interaction of interest is statistically significant (Ai and Norton, 2003; Norton, Wang, and Ai, 2004; Greene, 2009), we provide the estimated mean marginal effect for this variable along with the corresponding Z-statistic at the bottom of Table 2. We examined, but do not report, the graphical analyses suggested by these authors that plots the estimated interaction effects for various levels of the predicted probabilities. The interaction effect for CA_F2006 dummy is positive and statistically significant for all relevant levels of the predicted probability. These graphs are available upon request.

${ }^{24}$ We exclude the changes away from ChuoAoyama/Misuzu after fiscal 2006 because these switches are likely forced by the decision to shut down Misuzu.. Note that the sample size in Column (2) is lower than
} 
to Aarata as a change while in Column (2) estimation we do treat these observations as changes.

\section{[Place Table 2 here]}

The estimate on CA_F2006 indicates that the likelihood of an auditor change is higher in fiscal 2006 when ChuoAoyama was the incumbent auditor. We report both the regular logit marginal effect and the Ai and Norton (2003) marginal effect estimate for this variable. In the first specification, the Ai and Norton marginal effect on CA_FY2006 is 0.23 with an associated Z-statistic of 6.72 after applying the Ai and Norton (2003) and Norton et al. (2004) methodology. This implies, other variables held at their means, that a ChuoAoyama client is 23 percent more likely to switch auditors in fiscal year 2006, an effect that we attribute to reputation. The associated main effects show that ChuoAoyama client firms are, in general, less likely to switch away from ChuoAoyama than from other audit firms (marginal effect -.01) but more likely to switch in F2006 (marginal effect of .01) than in other years. These effects are, however, smaller and less significant than that for the interaction variable.

The results for the interaction term become stronger in Column (2) specification in Table 2, where we treat moves to Aarata as auditor changes, with the Ai and Norton marginal effect of 0.34 (z-statistic $=8.52)$. These results support the notion that there was an unusually high likelihood of switching away from ChuoAoyama in F2006, when doubts about the quality of that firm's audit practice manifested themselves in a significant way.

\section{Determinants of Auditor Switching for Former ChuoAoyama Clients}

in Column (1) because when we exclude the 52 Aarata observations as an auditor change, one of the industry fixed effects drops out because there is no variation in auditor change in that industry. 
We next examine the determinants of the choice to switch auditors to investigate our prediction that audit quality drives these switches. To do this, we use actual dates of the auditor changes to classify the 469 publicly listed ChuoAoyama clients in fiscal 2005 into three groups based on their auditor choices for fiscal 2006. The three principal groups are: ${ }^{25}$

1) 99 firms that did not use an interim auditor during the suspension and reverted to ChuoAoyama/Misuzu at the end of the suspension on September 1.

2) 199 firms that used an interim auditor for the period of the suspension and reverted to ChuoAoyama/Misuzu at the end of the suspension.

3) 155 firms that appointed a new auditor before the suspension began and continued to use that auditor after the suspension ended.

We view these choices as implying different relative levels of concern for audit quality. Firms in group (1) return to ChuoAoyama (Misuzu) after the suspension without using an interim auditor. These firms operated for two months without an external auditor and therefore were apparently relatively less concerned about audit quality. As discussed earlier and in footnote 11, regulators in Japan did not strictly enforce the requirement that firms need to have an external auditor at all times likely due to the supply disruption caused in the audit industry due to the ChuoAoyama suspension. Firms in group (2) return to ChuoAoyama/Misuzu after using an interim auditor for the period of the suspension. The use of an interim auditor indicates that the firm has the ability to comply with regulations and market expectations relating to audit quality thus signaling the

\footnotetext{
${ }^{25}$ Of the remaining 16 firms, nine had previously used two auditors and dropped ChuoAoyama during the suspension, and seven firms lack the requisite data.
} 
demand for higher audit quality than the first group of firms although our results continue to hold if we combine groups (1) and (2).

The third category is composed of 155 firms that switch to a new auditor for fiscal 2006, including the 145 firms that switch after the suspension was announced and the ten firms that switch before that time. Considering the substantial costs to switch auditors, the firms in this group likely value audit quality most highly relative to firms in the other two groups.

We consider the auditor switches to Aarata as changes that enhanced audit quality for a few reasons. ${ }^{26}$ First, its key management and most staff came from Aoyama, which was seen to have higher audit quality than Chuo, a judgment that interviewees repeatedly made to us. Second, its clients came disproportionately from Aoyama. Of the 52 former ChuoAoyama clients that shifted to Aarata at its inception on July 1, 2006, 14 had been clients of Aoyama (the Price Waterhouse affiliate) prior to the April 2000 merger of Chuo and Aoyama, 11 were previously clients of Chuo (the Coopers and Lybrand affiliate), while 18 were previously clients of other firms (data are unavailable for the remaining nine firms). Aarata took a much larger fraction of former Aoyama clients than it did former Chuo clients, consistent with information we gathered in our interviews that Aarata was staffed principally by former Aoyama personnel. ${ }^{27}$ Because Chuo was

\footnotetext{
${ }^{26}$ In a May 10, 2006 press release PwC announced the formation of a new firm Aarata that "will adopt international best practices...will meet high standards of audit quality...(and have a) high level of oversight by PwC.” Further, DiPiazza, then PwC's CEO, stated that Aarata's limited size reflected the availability of staff who met the firm's performance standards. Finally, when announcing Misuzu's closure on February 20, 2007 DiPiazza stated: "We would have hoped the Japanese profession evolved to a higher level of quality over the years. It did not. Cultural differences cannot be used as an excuse for lower quality" ("PwC to axe scandal-hit affiliate in Japan,” Financial Times, February 20, 2007). See also footnotes 2 and 13.

${ }^{27}$ There are at least three non-mutually exclusive explanations for the way clients switched to Aarata: (a) PwC encouraged some firms to move to Aarata to maintain the relationship given the size and visibility of these clients (e.g., Sony, Toyota, non-Japanese multinationals such as Unilever); (b) firms that were originally clients of Aoyama followed their external audit team to Aarata; (c) firms for which audit quality
} 
substantially larger than Aoyama, the numbers above imply that the majority of former Aoyama clients still with ChuoAoyama in fiscal 2005 (14 of 23 firms, or 60.9 percent) moved to Aarata. Only a small fraction (11 of 307 firms, or 3.6 percent) of former Chuo clients still with ChuoAoyama in fiscal 2005 moved to Aarata.

To investigate the auditor choice more formally, we fit an ordered logit model of these firms' auditor decisions for fiscal 2006. Using the groups described above, the dependent variable Switching is set to 0 for firms that went back to ChuoAoyama/Misuzu without using an interim auditor, 1 for firms that went back to ChuoAoyama/Misuzu after using an interim auditor, and 2 for firms that switched away from ChuoAoyama/Misuzu. The signal of the importance of audit quality conveyed by the above choices makes the dependent variable Switching an ordinal ranking of audit quality. Table 3 presents the results of this estimation. In the first estimation in Column 1 of Table 3 we drop all Aarata clients and in the second estimation in Column 2 we set the dependent variable to 2 for firms that moved to Aarata (a higher-quality audit alternative).

For the estimation in Table 3 we use largely the same set of independent variables as in Table 2 and add additional variables that we collected for the ChuoAoyama sample to capture cross-sectional variation in the demand for audit quality. All variables are defined in Appendix B. We include firm size (Log Total Assets), risk (Standard Deviation of Returns), and firm complexity (Number of Segments) as larger, riskier, and more complex firms need higher-quality audit effort. Firms with greater growth options (Market-to-Book Ratio) are likely to have greater information asymmetry between management and investors and hence are likely to demand higher audit quality. Leverage listings, or some combination thereof), made the switch due to audit quality concerns. These explanations are all consistent with these firms valuing audit quality relatively highly. 
is included to assess demand for high-quality auditing from debt holders. Firms with better performance as measured by ROA and Annual Returns may have lower demand for high audit quality. However, Landsman et al. (2009) find that firms with poor performance are more likely to change auditors.

We include three variables that measure the extent of foreign interaction of the clients to test if non-Japanese investors and stakeholders drive demand for higher-quality auditing. These variables are Foreign Ownership, Overseas Sales Ratio and U.S Listing. We expect firms belonging to a Keiretsu (Keiretsu Inclination) and those with a dominant owner-manager (Owner Manager) to have a lower likelihood of switching from ChuoAoyama since concentrated owners are an alternate monitoring channel that is a substitute for high-quality auditing. On the other hand, greater agency costs present in these ownership structures between the different classes of owners (concentrated versus public shareholders) might drive a demand for higher audit quality.

Clients may be reluctant to switch auditors if ChuoAoyama were the industry expert auditor, so we add Industry Expert Auditor as a determinant of the switching decision. Landsman et al. (2009) suggest that firms with high accruals entail greater audit risk, suggesting a need for higher-quality audits; hence, we include a measure of absolute discretionary accruals (AbsDiscAccrual). Similarly, firms that recently complete a merger or acquisition $(M \& A)$ also entail greater audit risk, suggesting need for higher-quality auditors. We include the stock returns on the suspension announcement date (Suspension Announcement Return) to examine if companies that suffered a more negative market reaction would be more likely to leave ChuoAoyama. Finally, industry fixed effects allow for possible systematic differences at the industry level. 


\section{[Place Table 3 here]}

We report the results of these regressions in Table 3. In both estimations, size (Log Total Assets) and Market-to-Book are both positively related to Switching at significance levels of 5 percent or less. ${ }^{28}$ This shows that larger firms and growth firms are more likely to move from ChuoAoyama to higher-quality auditors. These effects are economically significant—a one standard deviation increase in firm size leads to a 55 percent (69 percent) increase in the switching likelihood in Column 1 (Column 2), as seen in the changes in the odds ratios presented in the table. A similar change in marketto-book ratio leads to a change of 46 percent (37 percent) in Column 1 (Column 2). In both estimations, we find a reliably negative coefficient on Owner Manager defined as firms where the President or Chairman are among the top 10 shareholders, implying that firms with a dominant manager-shareholder, reflecting potential managerial entrenchment, are less likely to be concerned about audit quality. As an alternative to the entrenchment explanation, owner-managers could be less concerned about audit quality if they serve as a substitute monitoring mechanism, lowering investor demand for auditing. No other variables are consistently significant. ${ }^{29}$ To the extent that client firm size, market-to-book, and owner management are associated with a demand for higher audit quality, these results support our hypothesis that the auditor changes are explained by differential demands for audit quality. However, we do not observe a similar effect for measures of risk and firm complexity.

\footnotetext{
${ }^{28}$ We also estimated ordered logit models where the dependent variable is coded as 0 for firms that revert to Misuzu after the suspension, 1 for firms that switched to Aarata, and 2 for firms that switched to a firm other than Aarata (non-PwC). Results are similar to those reported here.

${ }^{29}$ In Column (1) companies with lower accounting quality as measured by absolute value to total discretionary accruals are more likely to switch auditors, suggesting that clients with potentially higher audit risk (Landsman et al. 2009) preferred to switch to a higher-quality auditor.
} 
As a robustness check, we test an alternate logit specification where we define firms that reverted to Misuzu as one group irrespective of whether they hired an interim auditor, with the dependent variable taking the value zero for clients that reverted to Misuzu and the value 1 if they switched auditors. Results (not tabulated) are similar to the ordered logit results. Size, market-to-book, and owner manager continue to be significant with the same signs. In addition, firm complexity as measured by number of segments becomes statistically significant, suggesting that more complex firms exhibit demand for higher-quality auditing.

Also consistent with the above results, Aarata's clients were two to three times larger based on total assets, sales, or market capitalization than those that stayed with Misuzu and 50 to 100 percent larger than those that moved to other audit firms. Aarata's clients also have higher levels of foreign ownership, overseas sales, and U.S. listings.

Finally, because it is unlikely that ChuoAoyama rejected larger clients in the aftermath of its suspension, our results are consistent with a demand-side effect in which client firms drive switching decisions. This contrasts with the results in Weber et al. (2008), who find that smaller firms and those with recent IPOs switched auditors, a result that is also consistent with a supply-side effect in which KPMG rejected smaller clients to reduce audit risk.

\section{Client Switching and Audit Personnel Moves}

We attribute the changes away from ChuoAoyama in 2006 to a decline in ChuoAoyama's audit quality. An alternative interpretation is that audit clients simply followed their audit teams from one audit firm to another. Blouin et al. (2007) provide evidence that a significant number of Andersen clients followed their audit teams to new 
audit firms following Andersen's demise in 2002 to minimize switching costs. Given the closeness of relationships between auditors and clients in Japan, we expect this to be an important phenomenon in Japan as well. On the other hand, if the goal of changing auditors is to improve quality, it is likely that clients would require a different audit team.

In Japan audit reports are signed by individual audit partners, which allows us to identify the partner(s) responsible for the audits. We report the results of analyzing the auditor signatory data in Table 4. In Panel A, for the set of client firms that switch away from ChuoAoyama between F2005 and F2006, including those that went to Misuzu and Aarata, we report data on the audit partner(s) who signed these firms' audit reports in fiscal 2005 on behalf of ChuoAoyama and then in fiscal 2006 on behalf of the new audit firm. We then classify the firm as either having at least one common signatory across years—which we interpret as implying the same audit team at the new firm—or not. ${ }^{30}$ The results show that there was a strong tendency for clients that stayed with PwC, at either Misuzu or Aarata, to have at least one common signatory, consistent with these audit firms having been formed from ChuoAoyama. Of the 50 Aarata clients that came from ChuoAoyama, 38 (76 percent) had signatories in common; of the 281 Misuzu clients, 239 (85 percent) had signatories in common. In strong contrast, none of the other switches had signatories in common with the fiscal 2005 ChuoAoyama auditors. The data thus clearly reject the interpretation that switches away from ChuoAoyama in fiscal 2006 were due to clients following their audit teams to new audit firms.

\section{[Place Table 4 here]}

\footnotetext{
${ }^{30}$ In a given year firms typically have one, two, or three auditor partners sign the report. Japan has mandatory auditor rotation (of audit partners within firms) so we do not expect these percentages to equal 100 percent even when there is no turnover.
} 
In Panel B of Table 4 we repeat the analysis for firms with signatory data available for fiscal years 2005 and 2007. The results are very different for these auditor changes. Here we find significant overlap in signatories for all the fiscal 2007 audit firms: 54 percent for Aarata, 35 percent for Azsa, 53 percent for ShinNihon, 27 percent for Tohmatsu, and 27 percent for other audit firms collectively. ${ }^{31}$ This is due to the movement of audit teams from Misuzu to other firms, consistent with the process we describe above for the winding up of Misuzu, under which audit team/client pairings tended to move to new audit firms together. It also reinforces our conclusion that the changes from fiscal years 2006 to 2007 are systematically different to those from fiscal years 2005 to 2006.

\section{Event Study Analysis}

Following previous research, we next analyze the market reaction to events associated with downward changes in the market’s beliefs about an auditor's quality (e.g. Menon and Williams 1994; Baber et al. 1995; Chaney and Philipich 2002; Weber et al. 2008). Because there is no significant litigation risk for auditors in Japan, any abnormally negative returns to ChuoAoyama clients at the time of these events are likely due to either changes in expectations about audit quality or switching costs, although switching was not forced at the time of these events. To identify relevant events, we search Factiva for media articles related to the Kanebo fraud or otherwise discussing ChuoAoyama, Misuzu, or Aarata during the period outlined in Section II. Important events are listed in Appendix A. ${ }^{32}$

\footnotetext{
${ }^{31}$ The number of firms in Table 4 panel A differs from that in panel B due to data constraints, either because we do not find the relevant filing or because some firms delist between fiscal years 2006 and 2007. ${ }^{32}$ We validate our set of events by comparing the dates to those in three other studies by Japanese authors. See Sakuma (2009), Numata and Takeda (2010), and Saito and Takeda (2011). We find substantial overlap
} 
Table 5 panel A provides mean and median market-adjusted returns for the threeday window centered on the event dates in Appendix A. Events 2, 4, 7, 9, 10, and 11 exhibit a statistically significant negative mean and median market reaction although the magnitudes are generally quite modest. The exception is event 9 with a mean return of 2.56 percent when PwC sent auditors from the U.S. and U.K. to address the problems at ChuoAoyama. Surprisingly, events 1 and 5 exhibit a small positive mean reaction. Following previous research, to address cross-sectional correlation among the contemporaneous daily stock returns of the ChuoAoyama client firms, we form a portfolio of these firms and estimate an adjusted market model regression using the timeseries of portfolio returns. ${ }^{33}$ Specifically, we estimate:

Return $_{\mathrm{t}}=\alpha_{0}+\beta_{1}$ Return $_{\mathrm{TSE} \text { INDEX } \mathrm{t}}+\theta_{\mathrm{k}}$ Event $_{\mathrm{k}, \mathrm{t}}+\varepsilon_{\mathrm{t}}$

Where Return $_{\mathrm{t}}$ is the return on day $\mathrm{t}$ to an equal-weighted portfolio of ChuoAoyama client firms, Return $_{\text {TSE INDEX, } \mathrm{t}}$ is the return on the TSE Topix index for day $\mathrm{t}$, and Event $\mathrm{k}_{\mathrm{t}, \mathrm{t}}$ is a dummy variable equal to one during the three-trading-day window centered on each of the eleven events, $k=1 \ldots 11$. We estimate the regression over the 798 trading days from January 1, 2004 through March 31, 2007, which includes the full set of events.

\section{[Place Table 5 here]}

in the dates, which provides assurance that we have identified the important events. These studies do not overlap with our work except in our event study analysis.

${ }^{33}$ We follow an approach similar to the multivariate regression model (MVRM) used previously by Schipper and Thompson (1983) and Bernard (1987). Under this approach, which Schipper and Thompson (ST) refer to as the joint GLS estimator, the time series of individual firms' returns is used to compute return cross-correlations. That is, the portfolio of returns is a weighted average of all the returns, where the weights are calculated based on the inverse of the variance-covariance matrix estimated from firm-by-firm regressions. To be effective, this procedure requires a large number of time-series observations relative to the number of sample firms (Bernard 1987, 6). Because we have a relatively large number of firms compared to the number of time-series observations we use a variant of the joint GLS approach also used by ST where we use unweighted averages of the firm-level returns, which assumes that the true covariance matrix is a scalar times the identity matrix. When we estimate the Table 5 regression specifications using the joint GLS estimator, the overall return is -0.06 percent $(t=-2.00)$. 
We estimate equation (1) for each of the events individually as well as for the combined set of events, and report results in Table 5, panel B. The results provide little evidence of any significant effect on most event dates. The coefficients on the event dummies are small and insignificant for ten of the eleven events. Consistent with the univariate results, the only exception is event 9 , which shows a return of -0.88 percent ( $t$ $=-3.56)$. When we combine the events, the coefficient on the overall event dummy is 0.15 percent $(\mathrm{t}=-1.94)$. This evidence offers at best modest support for the reputation argument. We also tested robustness of these results for a shorter window of time from June 1, 2004 to May 21, 2006 with 492 trading days and obtained similar results.

If the reputation argument matters more for larger, more prominent firms in Japan, then we might expect the event date results to be stronger for clients listed on the First Section TSE (larger, more prominent firms). ${ }^{34}$ These results (not tabulated) are similar to those we report in Table 5, with an overall return of -0.15 percent $(\mathrm{t}=-2.09) .{ }^{35}$ Overall, there is little evidence that any of these events is associated with economically significant abnormal event performance.

To summarize, the event study results provide little evidence that the former clients of ChuoAoyama suffered any material decline in value on the dates that we

\footnotetext{
${ }^{34}$ As another robustness check, we also examine the raw and market-adjusted returns for these firms in short windows around each of these events as well as for the subset listed on the First Section of the TSE. The market-adjusted returns to some of these events are significantly negative and significantly more negative than those for the non-ChuoAoyama clients. The magnitudes of these abnormal returns and the differences in abnormal returns, however, are quite small. These results are somewhat stronger when we restrict attention to stocks listed on the TSE First Section. Perhaps the strongest evidence in favor of an effect is the mean negative raw (market-adjusted) return of -3.14 percent (-0.64 percent) for First Section ChuoAoyama clients over a three-day window centered on the FSA suspension announcement (event 11) although the corresponding mean returns for non-ChuoAoyama clients are also negative, at -2.59 percent (0.10 percent). While statistically significant, differences between these amounts are small in economic magnitude.

${ }^{35}$ As a further robustness check, we also perform these tests using returns to a portfolio of all non-PwC clients in our sample as the benchmark rather than the market index returns (not reported in tables). There is again little evidence of systematically negative returns, with an overall return of -0.03 percent $(t=-1.48)$.
} 
identify. Numata and Takeda (2010) also conduct market reaction tests on the ChuoAoyama event dates. That paper includes four of our event dates-events 2, 3, 4, and 11 — and does not follow the Schipper and Thompson (1983) approach to the event study, instead carrying out a market model test for a sample of First Section companies only. They report results similar in magnitude and significance to our results in Panel A of Table 5 and conclude that the significant negative reaction indicates a reputational penalty. However, the multivariate regression approach following Schipper and Thompson (1983) and our larger set of dates weakens the estimates in our tests. Our results are in contrast to those in Weber et al. (2008), who find a statistically significant negative return for two out of their three event dates and for the combination of event dates. However, it is difficult to reach very strong conclusions based on this evidence given the relatively long time period over which concerns about ChuoAoyama's low audit quality were revealed. It could also be that these events had negative implications not just for ChuoAoyama clients but for firms generally in Japan, especially those on the TSE First Section, so that market-adjusting the returns removes the effect we are looking for. $^{36}$

\section{SUMMARY AND CONCLUSIONS}

In May 2006, the Japanese FSA took the unprecedented step of suspending the operations of ChuoAoyama, the PwC affiliate in Japan, for two months for its role in a major accounting fraud at Kanebo. Even as the suspension was announced, PwC was taking its own actions to remedy the apparent shortcomings of its Japanese unit. First, it

\footnotetext{
${ }^{36}$ For First Section TSE stocks the mean raw return for the ChuoAoyama clients on the suspension announcement date is -3.14 percent and for other TSE stocks is -2.59 percent, which is some evidence of this possibility.
} 
brought in high-level personnel from overseas to revamp ChuoAoyama's audit operations in an attempt to improve audit quality. Second, it set up a new, smaller Japanese affiliate, PwC Aarata, which it positioned as a high-quality audit firm. PwC used this firm to audit important Japanese clients like Toyota and Sony as well as the Japanese operations of large multinational clients such as Unilever. Third, when another major fraud came to light after ChuoAoyama resumed business as Misuzu, PwC shut down Misuzu, ceding a large part of its Japanese business to competitors. These actions make it clear that PwC viewed the audit quality issues at ChuoAoyama as potentially damaging to its international reputation, and support our view that an auditor's reputation for quality is of first-order importance.

We use these events to provide evidence on the importance of an auditor's reputation for quality. Previous studies using U.S. data have difficulty distinguishing the relative importance of an auditor's market-driven incentive to maintain a reputation for delivering quality audits versus the possibility that auditors are subject to potentially large, even catastrophic, legal liability for defective audits. Because litigation concerns are negligible in Japan, the litigation argument can effectively be ruled out. Consequently, we focus on whether these events provide evidence that supports the importance of auditor reputation.

Our results are largely consistent with the importance of reputation effects. We find evidence that a relatively large number of ChuoAoyama's clients left the firm for other auditors as the seriousness of ChuoAoyama's quality problems became evident. The rate of client turnover at ChuoAoyama in fiscal year 2006, before it became apparent that the firm would be shut down but after audit quality questions had been raised, was 
substantially higher than would otherwise be expected, consistent with clients leaving once the firm's reputation for quality was seriously diminished. Moreover, we find that the likelihood of switching is higher for larger clients and clients with higher market-tobook ratios, characteristics associated with a demand for higher audit quality, and lower for firms with greater managerial ownership, indicating a lower demand for audit quality in such firms. Clients that moved to Aarata were also larger, with higher market-to-book ratios, a greater extent of cross-listing, and higher foreign ownership. These switches are not the result of clients following their audit teams to new auditors. Our event study results weakly support the auditor quality argument but are likely to lack power because questions about ChuoAoyama's audit quality were revealed over an extended period.

Our conclusions are subject to two caveats. First, we find that clients switched away from ChuoAoyama in large numbers in the spring of 2006, just after Japanese regulators announced the two-month suspension and PwC formed Aarata. While we interpret these events as being a clear and undeniable signal of audit quality problems at ChuoAoyama, we cannot know for sure what drove these switches. It is possible that the suspension caused firms to switch auditors for reasons unrelated to audit quality. Second, our analysis presumes that audit quality is important to Japanese companies. While we believe this to be the case, especially over the past two decades as Japanese capital markets have evolved to be more like their western counterparts, it is possible that audit quality is less important in Japan generally. 
Significant Events in the Kanebo/ChuoAoyama Scandal, Including Events Used in Event Study Analysis

\begin{tabular}{|lrl|}
\hline & Date & Event \\
\hline Event 1 & $7 / 9 / 2004$ & Kanebo drops ChuoAoyama as auditor \\
Event 2 & $10 / 28 / 2004$ & Kanebo reports that the preliminary internal investigation has found fraud. Investigation continues. \\
& $\mathbf{3 / 3 1 / 2 0 0 5}$ & End of Fiscal 2004 \\
Event 3 & $4 / 13 / 2005$ & $\begin{array}{l}\text { Results of fraud investigation announced by Kanebo. Will restate last five years of financial } \\
\text { statements. }\end{array}$ \\
Event 4 & $7 / 29 / 2005$ & Three former Kanebo executives are arrested. CA offices are searched. \\
Event 5 & $8 / 18 / 2005$ & Indictments brought against ChuoAoyama auditors. \\
Event 6 & $9 / 13 / 2005$ & Four auditors from CA who audited Kanebo are arrested. \\
Event 7 & $9 / 19 / 2005$ & Top executives from CA are questioned by prosecutors. \\
Event 8 & $10 / 3 / 2005$ & CA partners step down. Three CA auditors indicted. FSA indicates it will impose penalties on CA. \\
Event 9 & $2 / 20 / 2006$ & PwC sends team of auditors from U.K. and U.S. to revamp ChuoAoyama. \\
Event 10 & $3 / 30 / 2006$ & ChuoAoyama accountants plead guilty of falsifying Kanebo financials. \\
& $\mathbf{3 / 3 1 / 2 0 0 6}$ & End of Fiscal 2005 \\
Event 11 & $5 / 10 / 2006$ & CA suspension announced; PwC announces two-firm formula with creation of a new, higher-quality \\
& & firm. \\
& $\mathbf{3 / 3 1 / 2 0 0 7}$ & End of Fiscal 2006 \\
\hline
\end{tabular}




\section{APPENDIX B: Variable Definitions}

The table provides definitions and data sources for all the variables in subsequent tests. JCH stands for Japan Company Handbook. USD stands for United States Dollar.

\begin{tabular}{|c|c|c|}
\hline Variable Name & Definition & Source \\
\hline Switching & $\begin{array}{l}\text { Ordinal ranking of audit quality that takes the value } 0 \text { for firms that } \\
\text { went back to ChuoAoyama/Misuzu after the suspension without } \\
\text { using an interim auditor, } 1 \text { for firms that went back to } \\
\text { ChuoAoyama/Misuzu after using an interim auditor, and } 2 \text { for firms } \\
\text { that switched away from ChuoAoyama/Misuzu. }\end{array}$ & $\begin{array}{l}\text { Company } \\
\text { Filings }\end{array}$ \\
\hline Market Cap & Market value of equity in USD Millions & Worldscope \\
\hline Total Assets & Total assets in USD Millions & Worldscope \\
\hline $\begin{array}{l}\text { Log Total } \\
\text { Assets }\end{array}$ & Natural log of total assets & Worldscope \\
\hline $\begin{array}{l}\text { Market-to- } \\
\text { Book }\end{array}$ & Market value of equity/book value of equity & Worldscope \\
\hline Leverage & Long-term debt divided by total assets & Worldscope \\
\hline Net Income & Net Income in USD Million & Worldscope \\
\hline ROA & Net income divided by total assets & Worldscope \\
\hline Loss & $\begin{array}{l}\text { Indicator variable that takes the value } 1 \text { if net income is less than zero } \\
\text { and } 0 \text { otherwise. }\end{array}$ & \\
\hline Annual Returns & Fiscal year stock returns & Datastream \\
\hline $\begin{array}{l}\text { Foreign } \\
\text { Ownership }\end{array}$ & Percent ownership of the firm's equity by foreign entities & $\mathrm{JCH}, 2004$ \\
\hline $\begin{array}{l}\text { Overseas Sales } \\
\text { Ratio }\end{array}$ & Ratio of sales outside Japan to total sales, expressed in percentage & $\mathrm{JCH}, 2004$ \\
\hline $\begin{array}{l}\text { Number of } \\
\text { Segments }\end{array}$ & $\begin{array}{l}\text { Number of distinct divisions for which shares of total sales are } \\
\text { reported }\end{array}$ & $\mathrm{JCH}, 2004$ \\
\hline Firm Age & Years since the firm was founded & $\mathrm{JCH}, 2004$ \\
\hline US Listing & $\begin{array}{l}\text { All U.S. listings, including those via stock exchange, portal, and the } \\
\text { OTC }\end{array}$ & $\begin{array}{l}\text { Citibank ADR } \\
\text { database }\end{array}$ \\
\hline $\begin{array}{l}\text { Std Dev } \\
\text { Returns }\end{array}$ & Firm-level standard deviation of daily stock returns in 2005 & Datastream \\
\hline Industry & Industry affiliation of the company & $\begin{array}{l}\text { Tokyo Stock } \\
\text { Exchange }\end{array}$ \\
\hline
\end{tabular}




\begin{tabular}{|c|c|c|}
\hline Variable Name & Definition & Source \\
\hline TSE Index & $\begin{array}{l}\text { The Tokyo Stock Price Index (TOPIX) is a composite index of all } \\
\text { common stocks listed on the first section of the Tokyo Stock } \\
\text { Exchange. }\end{array}$ & Datastream \\
\hline $\begin{array}{l}\text { Keiretsu } \\
\text { Inclination }\end{array}$ & $\begin{array}{l}\text { Keiretsu inclination measures the closeness to the keiretsu, with } \\
\text { higher numbers indicating a closer inclination. There are two types of } \\
\text { keiretsu, horizontal (also known as "main bank groups") and vertical; } \\
\text { for horizontals, the data are from Part III of the book, and for } \\
\text { verticals, from Part II. The most recent edition of the source (2001) } \\
\text { provides information as of } 2000 \text {. }\end{array}$ & $\begin{array}{l}\text { Industrial } \\
\text { Groupings in } \\
\text { Japan }\end{array}$ \\
\hline & $\begin{array}{l}\text { This variable ranges from } 0 \text { for companies that are not part of a } \\
\text { keiretsu to } 4 \text { for companies with the highest level of inclination } \\
\text { ("nucleus" group companies). The measured inclination is based on } \\
\text { five factors: (i) the characteristics and historical background of the } \\
\text { groups and/or the company; (ii) sources and amount of bank loans; } \\
\text { (iii) board of directors sent by and/or sent to nucleus and/or other } \\
\text { group companies; (iv) the company attitude towards the group; and } \\
\text { (v) the company's connections with other groups and/or non-group } \\
\text { companies. }\end{array}$ & \\
\hline Audit Fees & Audit fees paid to ChuoAoyama for FY 2005 in USD Millions & $\begin{array}{l}\text { Company } \\
\text { filings }\end{array}$ \\
\hline $\begin{array}{l}\text { Owner } \\
\text { Manager }\end{array}$ & $\begin{array}{l}\text { Indicator variable that takes the value } 1 \text { if the president or Chairman } \\
\text { of the company are among the top } 10 \text { shareholders of the company } \\
\text { and } 0 \text { otherwise. Measured only for ChuoAoyama clients. }\end{array}$ & $\mathrm{JCH}, 2004$ \\
\hline $\begin{array}{l}\text { Industry Expert } \\
\text { Auditor }\end{array}$ & $\begin{array}{l}\text { Indicator that takes the value } 1 \text { when the audit firm audits greater } \\
\text { than } 20 \text { percent of clients (weighted by total assets) in a given } \\
\text { industry and } 0 \text { otherwise. }\end{array}$ & Datastream \\
\hline $\begin{array}{l}\text { Abs Disc } \\
\text { Accrual }\end{array}$ & $\begin{array}{l}\text { Absolute value of total discretionary accruals estimated as per } \\
\text { Defond and Subramanyam (1998). }\end{array}$ & Datastream \\
\hline$M \& A$ & $\begin{array}{l}\text { Indicator variable that takes the value } 1 \text { when the firm has completed } \\
\text { an M\&A transaction in the prior two years and } 0 \text { otherwise. }\end{array}$ & Thomson SDC \\
\hline $\begin{array}{l}\text { Suspension } \\
\text { Announcement } \\
\text { Returns }\end{array}$ & $\begin{array}{l}\text { Stock returns on three-day window around the date the ChuoAoyama } \\
\text { suspension was announced - May 10, } 2006\end{array}$ & Datastream \\
\hline
\end{tabular}




\section{REFERENCES}

Ai, C., and E. C. Norton. 2003. Interaction terms in logit and probit models. Economics Letters 80: 123-129.

Aoki, M., H. Patrick, and P. Sheard. 1994. The Japanese main bank system: An introductory overview. In The Japanese Main Bank System, edited by M. Aoki and H. Patrick. Oxford, UK: Oxford University Press.

Baber, W., K. Kumar, and T. Verghese. 1995. Client security price reactions to the Laventhol and Horwath bankruptcy. Journal of Accounting Research 33: 385-395.

Ball, R. 2009. Market and political/regulatory perspectives on the recent accounting scandals. Journal of Accounting Research 47: 277-323.

Barton, J. 2005. Who cares about auditor reputation? Contemporary Accounting Research 22: 549-586.

Basioudis, I., and J. Francis. 2007. Audit pricing in the United Kingdom: Tests of big 4 audit fee premia for brand name, industry leadership and city leadership. Auditing: A Journal of Practice and Theory 26 (2): 143-166.

Bernard, V. 1987. Cross-sectional dependence and problems in inference in market-based accounting research. Journal of Accounting Research 25: 1-48.

Blouin, J., B. M. Grein, and B. R. Rountree. 2007. An analysis of forced auditor change: The case of former Arthur Andersen clients. The Accounting Review 82: 621-650.

Cahan, S. F., D. Emanuel, and J. Sun. 2009. Are the reputations of the large accounting firms really international? Evidence from the Andersen-Enron affair. Auditing: A Journal of Theory and Practice 28: 199-226.

Chaney, P., and K. Philipich. 2002. Shredded reputation: The cost of audit failure. Journal of Accounting Research 40: 1221-1246.

DeAngelo, L. 1981. Auditor size and audit quality. Journal of Accounting and Economics 3: 183-199.

DeFond, M. L. 1992. The association between changes in client firm agency costs and auditor switching. Auditing: A Journal of Theory and Practice 11: 16-31.

— and K. R. Subramanyam. 1998. Auditor changes and discretionary accruals. Journal of Accounting and Economics 25: 36-67.

Ferguson, A., J. Francis, and D. Stokes. 2003. The effects of firm-wide and office-level industry expertise on audit pricing. The Accounting Review 78 (2): 429-448. 
Francis, J. R., and E. R. Wilson. 1988. Auditor changes: A joint test of theories relating to agency costs and auditor differentiation. The Accounting Review 63: 663-682.

K. Reichelt, and D. Wang. 2005. The pricing of national and city-specific reputations for industry expertise in the U.S. audit market. The Accounting Review 80 (1): 113-136.

, and M. Yu. 2009. The Effect of Big Four Office Size on Audit Quality, The Accounting Review 84 (5): 1521-1552.

Ginsburg, T., and G. Hoetker. 2006. The unreluctant litigant? An empirical analysis of Japan’s turn to litigation. Journal of Legal Studies 35: 31-59.

Greene, W.H. 2009. Testing hypotheses about interaction terms in nonlinear models. Working paper, New York University. July 15. Available at: http://w4.stern.nyu.edu/ economics/docs/workingpapers/2009/Interaction-Terms-in-Nonlinear-Models.pdf.

Hawkins, D. F., S. Srinivasan, A. Kanno, and L. Gomez. 2010. Kanebo Ltd. (A). Harvard Business School Case 111-037.

Hennes, K. M., A. J. Leone, and B. P. Miller. 2011. Accounting restatements and auditor accountability. Working paper, University of Oklahoma, University of Miami, and Indiana University. January 5. Available at SSRN: http://ssrn.com/ abstract $=1735675$.

Hoshi, T., and A. K. Kashyap. 2001. Corporate Financing and Governance in Japan: The Road to the Future. Cambridge, MA: The MIT Press.

Hosono, Y. 2008. Forensic versus Securities Fraud. Tokyo: Nikkei BP. In Japanese.

Kanodia, C., and A. Mukherji. 1994. Audit pricing, lowballing and audit turnovers: A dynamic analysis. The Accounting Review 69 (4): 593-615.

Khurana, I., and K. Raman. 2004. "Litigation risk and the financial reporting credibility of Big 4 vs. Non-Big 4 audits: Evidence from Anglo American countries.” The Accounting Review 79 (April): 473-495.

Kohlbeck, M. J., B. W. Mayhew, P. R. Murphy, and M. S. Wilkins. 2008. Competition for Andersen clients. Contemporary Accounting Research 25 (4): 1099-1136.

Krishnamurthy, S., J. Zhou, and N. Zhou. 2006. Auditor reputation, auditor independence, and the stock market impact of Andersen's indictment on its client firms. Contemporary Accounting Research 23 (2): 465-490.

Kyodo News International. 2006. Auditing firms urged not to take customers from 
ChuoAoyama. Kyodo News (May 11).

Landsman, W. R., K. K. Nelson, and B. R. Rountree. 2009. Auditor switches in the preand post-Enron eras: Risk or realignment? The Accounting Review 84: 531-558.

Lennox, C. S. 1999. Audit quality and auditor size: An evaluation of reputation and deep pockets hypotheses. Journal of Business Finance \& Accounting 26: 779-805.

Menon, K., and D. Williams. 1994. The insurance hypothesis and market prices. The Accounting Review 69: 327-342.

Murase, H., S. Numata, and F. Takeda. 2010. Reputation of Low-Quality Big 4 and NonBig 4 Auditors: Evidence from Auditor Switches of Former ChuoAoyama Clients.” Working paper, available at SSRN: http://ssrn.com/abstract=1532207

Nelson, K. N., R. A. Price, and B. R. Rountree. 2008. The market reaction to Arthur Andersen's shredding of documents: Loss of reputation or confounding effects? Journal of Accounting and Economics 46: 279-293.

Norton, E. C., H. Wang, and C. Ai. 2004. Computing interaction effects and standard errors in logit and probit models. The Stata Journal 4: 154-167.

Numata, S., and F. Takeda. 2010. Stock market reactions to audit failure in Japan: The case of Kanebo and ChuoAoyama. International Journal of Accounting 45 (2): 175199.

Ramnath, S., and J. Weber. 2008. Discussion of "Competition for Andersen clients.” Contemporary Accounting Research 25 (4): 1137-1146.

Reynolds, J. K., and J. Francis. 2000. Does size matter? The influence of large clients on office-level auditor reporting decisions. Journal of Accounting and Economics 30 (3): 375-400.

Sakuma, Y. 2009. Loss of an auditor's reputation and client stock price reactions: Evidence from Japan. Working paper, Fuji University, presented at the 2009 American Accounting Association annual meeting in New York City.

Schipper, K., and R. Thompson. 1983. The impact of merger-related regulation on the shareholders of acquiring firms. Journal of Accounting Research 21: 184-221.

Shu, S. Z. 2000. Auditor resignations: Clientele effects and legal liability. Journal of Accounting and Economics 29: 173-205.

Saito, Yoshie and Takeda, Fumiko, 2011. Global Audit Firm Networks and Reputation Risk: Evidence from Japan and the U.S. Available at http://ssrn.com/abstract=1326005 
Weber, J., Willenborg, M., and J. Zhang. 2008. Does auditor reputation matter? The case of KPMG Germany and ComROAD AG. Journal of Accounting Research 46: 941972.

West, M. D. 2001. Why shareholders sue: The evidence from Japan. Journal of Legal Studies 30: 351-382.

Willenborg, M. 1999. "Empirical analysis of the economic demand for auditing in the Initial Public Offerings market.” Journal of Accounting Research 37 (Spring): 225238. 


\section{TABLE 1}

Market Share Analysis of Japanese Audit Market

Big Auditor refers to the following audit firms, with their affiliations to worldwide audit networks in parentheses: ChuoAoyama/Misuzu/Aarata (PwC), Asahi (Andersen), AZSA (KPMG), ShinNihon (Ernst \& Young), and Tohmatsu (Deloitte). Non Big Auditor are all other audit firms. Size of client is measured by market capitalization at the end of the fiscal year. The count of companies in all panels includes only those firms for whom market capitalization data are available.

\section{Panel A: Distribution of Clients across Time}

\begin{tabular}{r|rrr|rrr|r}
\hline $\begin{array}{r}\text { Fiscal } \\
\text { Year }\end{array}$ & $\begin{array}{l}\text { Big } \\
\text { Auditor }\end{array}$ & $\begin{array}{l}\text { Big Auditor } \\
\text { \% by } \\
\text { Number of } \\
\text { Clients }\end{array}$ & $\begin{array}{l}\text { Big Auditor } \\
\text { \% by Size of } \\
\text { Client }\end{array}$ & $\begin{array}{r}\text { Non Big } \\
\text { Auditor }\end{array}$ & $\begin{array}{l}\text { Non Big } \\
\text { Auditor } \\
\text { \% by } \\
\text { Number } \\
\text { of Clients }\end{array}$ & $\begin{array}{l}\text { Non Big } \\
\text { Auditor \% } \\
\text { by Size of } \\
\text { Client }\end{array}$ & $\begin{array}{l}\text { All Audit } \\
\text { Firms }\end{array}$ \\
\hline F2001 & 1,565 & $81.2 \%$ & $93.6 \%$ & 363 & $18.8 \%$ & $6.4 \%$ & 1,928 \\
F2002 & 1,757 & $82.0 \%$ & $93.4 \%$ & 386 & $18.0 \%$ & $6.6 \%$ & 2,143 \\
F2003 & 1,820 & $82.1 \%$ & $93.6 \%$ & 396 & $17.9 \%$ & $6.4 \%$ & 2,216 \\
F2004 & 1,852 & $82.9 \%$ & $94.4 \%$ & 382 & $17.1 \%$ & $5.6 \%$ & 2,234 \\
F2005 & 1,871 & $83.8 \%$ & $95.1 \%$ & 361 & $16.2 \%$ & $4.9 \%$ & 2,232 \\
F2006 & 1,857 & $83.3 \%$ & $95.3 \%$ & 372 & $16.7 \%$ & $4.7 \%$ & 2,229 \\
F2007 & 1,723 & $81.2 \%$ & $92.4 \%$ & 399 & $18.8 \%$ & $7.6 \%$ & 2,122 \\
Total & 12,445 & $82.4 \%$ & $94.1 \%$ & 2,659 & $17.6 \%$ & $5.9 \%$ & 15,104 \\
\hline
\end{tabular}

Panel B: Time Series Distribution of Number of Clients across Big Auditors

\begin{tabular}{|c|c|c|c|c|c|c|c|c|c|}
\hline \multirow{3}{*}{$\begin{array}{l}\text { Fiscal } \\
\text { Year }\end{array}$} & \multicolumn{7}{|c|}{ Big Auditor } & \multirow{3}{*}{$\begin{array}{l}\text { Non Big } \\
\text { Auditor }\end{array}$} & \multirow{3}{*}{$\begin{array}{l}\text { All } \\
\text { Audit } \\
\text { Firms }\end{array}$} \\
\hline & \multicolumn{3}{|c|}{$\begin{array}{c}\text { PwC Related } \\
\text { Firms }\end{array}$} & \multicolumn{4}{|c|}{ Other Big Audit Firms } & & \\
\hline & $\begin{array}{l}\text { Chuo- } \\
\text { Aoyama }\end{array}$ & isuzu & ata & Asahi & Azsa & $\begin{array}{l}\text { Shin } \\
\text { Nihon }\end{array}$ & Tohmatsu & & \\
\hline F2001 & 396 & 0 & 0 & 324 & 0 & 465 & 380 & 363 & 1,928 \\
\hline F2002 & 452 & 0 & 0 & 348 & 4 & 515 & 438 & 386 & 2,143 \\
\hline F2003 & 464 & 0 & 0 & 12 & 373 & 518 & 453 & 396 & 2,216 \\
\hline F2004 & 471 & 0 & 0 & 0 & 395 & 525 & 461 & 382 & 2,234 \\
\hline F2005 & 469 & 0 & 0 & 0 & 410 & 532 & 460 & 361 & 2,232 \\
\hline F2006 & 7 & 303 & 52 & 0 & 443 & 573 & 479 & 372 & 2,229 \\
\hline F2007 & 0 & 15 & 60 & 0 & 473 & 674 & 501 & 399 & 2,122 \\
\hline
\end{tabular}


Panel C: Time Series Distribution of Clients Weighted by Market Capitalization

\begin{tabular}{|c|c|c|c|c|c|c|c|c|c|}
\hline \multirow{3}{*}{$\begin{array}{l}\text { Fiscal } \\
\text { Year }\end{array}$} & \multicolumn{7}{|c|}{ Big Auditor } & \multirow{3}{*}{$\begin{array}{l}\text { Non Big } \\
\text { Auditor }\end{array}$} & \multirow{3}{*}{$\begin{array}{l}\text { All Audit } \\
\text { Firms }\end{array}$} \\
\hline & \multicolumn{3}{|c|}{ PwC Related Firms } & \multicolumn{4}{|c|}{ Other Big Audit Firms } & & \\
\hline & $\begin{array}{l}\text { Chuo- } \\
\text { Aoyama }\end{array}$ & Misuzu & Aarata & Asahi & Azsa & $\begin{array}{l}\text { Shin } \\
\text { Nihon }\end{array}$ & Tohmatsu & & \\
\hline F2001 & $26.68 \%$ & $0.00 \%$ & $0.00 \%$ & $19.48 \%$ & $0.00 \%$ & $28.06 \%$ & $19.42 \%$ & $6.36 \%$ & $100.0 \%$ \\
\hline F2002 & $25.16 \%$ & $0.00 \%$ & $0.00 \%$ & $19.22 \%$ & $0.60 \%$ & $28.36 \%$ & $20.04 \%$ & $6.62 \%$ & $100.0 \%$ \\
\hline F2003 & $27.27 \%$ & $0.00 \%$ & $0.00 \%$ & $0.08 \%$ & $20.85 \%$ & $26.40 \%$ & $19.03 \%$ & $6.37 \%$ & $100.0 \%$ \\
\hline F2004 & $26.28 \%$ & $0.00 \%$ & $0.00 \%$ & $0.00 \%$ & $21.07 \%$ & $26.98 \%$ & $20.12 \%$ & $5.55 \%$ & $100.0 \%$ \\
\hline F2005 & $24.16 \%$ & $0.00 \%$ & $0.00 \%$ & $0.00 \%$ & $23.95 \%$ & $25.74 \%$ & $21.23 \%$ & $4.92 \%$ & $100.0 \%$ \\
\hline F2006 & $0.09 \%$ & $11.71 \%$ & $8.83 \%$ & $0.00 \%$ & $25.63 \%$ & $26.04 \%$ & $23.02 \%$ & $4.68 \%$ & $100.0 \%$ \\
\hline F2007 & $0.00 \%$ & $0.16 \%$ & $9.33 \%$ & $0.00 \%$ & $29.73 \%$ & $28.10 \%$ & $25.13 \%$ & $7.55 \%$ & $100.0 \%$ \\
\hline
\end{tabular}

\section{Panel D: Turnover Rate in Big and Non Big Auditors}

The table presents the auditor turnover rate for the sample firms. Change of auditor from ChuoAyoama to Misuzu or Aarata is not counted as an auditor change. Big Auditors refer to local affiliates of the large international audit networks. These are ChuoAoyama/Misuzu/Aarata (PwC), Asahi (Arthur Andersen), AZSA (KPMG), ShinNihon (Ernst \& Young), and Tohmatsu (Deloitte). Non Big Auditors are all other audit firms in Japan.

\begin{tabular}{llcc}
\hline $\begin{array}{l}\text { Fiscal } \\
\text { Year }\end{array}$ & $\begin{array}{l}\text { Big Auditor } \\
\text { Excluding } \\
\text { ChuoAoyama } \\
\text { and Misuzu }\end{array}$ & Non Big Auditor & ChuoAoyama and Misuzu \\
\hline F2002 & $0.9 \%$ & $8.0 \%$ & \\
F2003 & $2.5 \%$ & $3.1 \%$ & $0.5 \%$ \\
F2004 & $0.6 \%$ & $8.1 \%$ & $1.3 \%$ \\
F2005 & $1.2 \%$ & $7.6 \%$ & $1.5 \%$ \\
F2006 & $1.2 \%$ & $10.7 \%$ & $1.7 \%$ \\
F2007 & $1.9 \%$ & $10.6 \%$ & $23.7 \%$ \\
\hline
\end{tabular}




\section{Panel E: Month of Switch to Final Auditor by ChuoAoyama Clients}

The table presents the number of ChuoAoyama clients that switched during each month in 2006 and 2007 to their final choice of auditor, which we define as the auditor for fiscal year 2007. The sample in Column (A) is all clients that leave ChuoAoyama and do not revert to Misuzu. Column (B) consists of clients that reverted to Misuzu but hired an interim auditor during the suspension. Column (C) is the sample of ChuoAoyama clients that reverted to Misuzu but had no interim auditor during the suspension period. Column (D) is all ChuoAoyama clients, i.e. the sum of columns A, B, and C.

\begin{tabular}{|c|c|c|c|c|}
\hline $\begin{array}{l}\text { Month } \\
\text { Switched to } \\
\text { Final Auditor }\end{array}$ & $\begin{array}{l}\text { A: Leave } \\
\text { ChuoAoyama, Do } \\
\text { Not Revert to } \\
\text { Misuzu }\end{array}$ & $\begin{array}{l}\text { B: Choose } \\
\text { Interim } \\
\text { Auditor, } \\
\text { Revert to } \\
\text { Misuzu }\end{array}$ & $\begin{array}{l}\text { C: No Interim } \\
\text { Auditor, } \\
\text { Revert to } \\
\text { Misuzu }\end{array}$ & $\begin{array}{l}\text { D: All } \\
\text { ChuoAoyama } \\
\text { Clients }\end{array}$ \\
\hline Feb-06 & 5 & & & 5 \\
\hline Mar-06 & 0 & & & 0 \\
\hline Apr-06 & 5 & & & 5 \\
\hline May-06 & 38 & & & 38 \\
\hline Jun-06 & 25 & & & 25 \\
\hline Jul-06 & 82 & & & 82 \\
\hline Aug-06 & & & & 0 \\
\hline Sep-06 & & & & 0 \\
\hline Oct-06 & & & & 0 \\
\hline Nov-06 & & & & 0 \\
\hline Dec-06 & & 1 & & 1 \\
\hline Jan-07 & & 0 & 1 & 1 \\
\hline Feb-07 & & 3 & 2 & 5 \\
\hline Mar-07 & & 5 & 1 & 6 \\
\hline Apr-07 & & 28 & 5 & 33 \\
\hline May-07 & & 132 & 66 & 198 \\
\hline Jun-07 & & 12 & 5 & 17 \\
\hline Jul-07 & & 12 & 14 & 26 \\
\hline Aug-07 & & 4 & 4 & 8 \\
\hline Sep-07 & & 2 & 1 & 3 \\
\hline Total & 155 & 199 & 99 & 453 \\
\hline
\end{tabular}


TABLE 2

\title{
Auditor Change Logit Regressions: Changes Away from ChuoAoyama
}

\begin{abstract}
AuditorChange ${ }_{\mathrm{i}, \mathrm{t}}=\alpha_{0}+\alpha_{1} C A_{\mathrm{i}, \mathrm{t}-1}+\alpha_{2} \mathrm{~F} 2006+\alpha_{3} C_{\mathrm{i}, \mathrm{t}-1} * \mathrm{~F} 2006+\alpha_{4} \log _{\text {Total Assets }} \mathrm{i, \textrm {t } - 1}+$ $\alpha_{5} \% \Delta$ TotalAssets $\mathrm{i}_{\mathrm{i}-\mathrm{-}-1}+\alpha_{6}$ Leverage $_{\mathrm{i}, \mathrm{t}-1}+\alpha_{7}$ LLeverage $_{\mathrm{i}, \mathrm{t}-1}+\alpha_{8}$ ROA $_{\mathrm{i}, \mathrm{t}-1}+\alpha_{9}$ Loss $_{\mathrm{i}, \mathrm{t}-1}+\alpha_{10}$ U.S. $_{\text {Listing }} \mathrm{i,-}$ ${ }_{1}+\alpha_{11}$ Keiretsu Inclination $_{\mathrm{i}, \mathrm{t}-1}+\alpha_{12}$ Industry Expert Auditor $_{\mathrm{i}, \mathrm{t}-1}+\alpha_{13}$ Abs Disc Accruals $_{\mathrm{i}, \mathrm{t}-1}+\alpha_{14}$ $M \& A_{\mathrm{i}, \mathrm{t}-1}+$ Industry Fixed Effects $+\varepsilon$
\end{abstract}

AuditorChange takes the value 1 when the auditor the next fiscal year is not the same as in the current fiscal year. Data are from fiscal year 2001 to fiscal year 2006 (inclusive). Auditor change from ChuoAyoma to Misuzu is not counted as a change. Change from ChuoAoyama to Aarata is not considered a change in Column (1) and is counted as a change in Column (2). Z-statistics are based on robust standard errors reported are in parentheses. Marginal effects are computed at the means of the independent variables except for dummy variables, where it is the change in value from 0 to 1 . The Ai and Norton marginal effects and Z-statistics on the interaction term are calculated following Norton, Wang, and Ai (2004).

\begin{tabular}{|c|c|c|c|c|c|c|}
\hline \multirow[t]{2}{*}{ Variable } & \multicolumn{3}{|c|}{$\begin{array}{c}\text { Column (1) - Excludes Moves to } \\
\text { Aarata }\end{array}$} & \multicolumn{3}{|c|}{$\begin{array}{c}\text { Column (2) - Includes Moves to } \\
\text { Aarata }\end{array}$} \\
\hline & Coeff & Z-statistic & $\begin{array}{l}\text { Marginal } \\
\text { Effects }\end{array}$ & Coeff & Z-statistic & $\begin{array}{l}\text { Marginal } \\
\text { Effects }\end{array}$ \\
\hline Constant & -2.37 & $(-2.08)^{* *}$ & & -2.70 & $(-6.59) * * *$ & \\
\hline CA & -0.52 & $(-2.26)^{* *}$ & -0.01 & -0.55 & $(-2.38)^{* *}$ & -0.01 \\
\hline F2006 & 0.34 & $(2.08)^{* *}$ & 0.01 & 0.33 & $(2.01)^{* *}$ & 0.01 \\
\hline CA_F2006 & 2.91 & $(10.18)^{* * *}$ & 0.25 & 3.47 & $(12.30)^{* * *}$ & 0.37 \\
\hline Log Total Assets & -0.08 & $(-1.54)$ & -0.00 & -0.02 & $(-0.36)$ & -0.00 \\
\hline$\% \Delta$ TotalAssets & 0.02 & $(1.42)$ & 0.00 & 0.02 & (1.09) & 0.00 \\
\hline Leverage & -0.15 & $(-0.46)$ & 0.00 & -0.21 & $(-0.65)$ & -0.00 \\
\hline$\Delta$ Leverage & 0.12 & $(0.11)$ & 0.00 & 0.21 & $(0.20)$ & 0.00 \\
\hline ROA & -0.03 & $(-1.69)^{*}$ & -0.00 & -0.03 & $(-1.75)^{*}$ & -0.00 \\
\hline Loss & 0.33 & $(1.63)$ & 0.01 & 0.28 & $(1.38)$ & 0.01 \\
\hline U.S. Listing & 0.41 & (1.61) & 0.01 & 0.40 & $(1.73)^{*}$ & 0.01 \\
\hline Keiretsu Inclination & -0.03 & $(-0.59)$ & -0.00 & -0.06 & $(-1.17)$ & -0.00 \\
\hline Industry Expert Auditor & -0.64 & $(-4.93)^{* * *}$ & -0.01 & -0.55 & $(-4.52)^{* * *}$ & -0.01 \\
\hline Abs Disc Accrual & 2.22 & $(4.10)^{* * *}$ & 0.05 & 2.40 & $(3.95)^{* * *}$ & 0.05 \\
\hline$M \& A$ & 0.23 & $(1.68)^{*}$ & 0.01 & 0.18 & $(1.36)$ & 0.00 \\
\hline Industry Fixed Effects & Included & & & Included & & \\
\hline Observations & 10723 & & & 10798 & & \\
\hline Pseudo R Sq & 0.1362 & & & 0.1937 & & \\
\hline $\begin{array}{l}\text { Ai and Norton Marginal } \\
\text { Effect for CA_F2006 }\end{array}$ & & $(6.72)^{* * *}$ & 0.23 & & $(8.52)^{* * *}$ & 0.34 \\
\hline $\begin{array}{ll}*, * * & \text {, and } * * * \\
\text { Variables not defines ent signifi }^{*} \text { earlier } \\
\text { AuditorChange }_{\mathrm{t}} & : 1 \text { if the a } \\
\text { CA } & : 1 \text { if Chu } \\
\text { F2006 } & : 1 \text { if fisca } \\
\text { CA_F2006 } & : 1 \text { if Chu } \\
\% \Delta \text { TotalAssets }_{\mathrm{t}}: \text { Percenta } \\
\Delta \text { Leverage }_{\mathrm{t}} \quad: \text { Change }\end{array}$ & $\begin{array}{l}\text { ice at the } 10 \% \\
\text { it firm chang } \\
\text { oyama is the } \\
\text { ear is } 2006 \text {; } \\
\text { oyama is the } \\
\text { change in to } \\
\text { everage fror }\end{array}$ & $\begin{array}{l}5 \% \text {, and } 1 \% \text { lev } \\
\text { s from year t- } \\
\text { prior year audi } \\
\text { otherwise } \\
\text { audit firm in } F \\
\text { al assets from } \\
\text { year t-1 }\end{array}$ & $\begin{array}{l}\text { respectively } \\
0 \text { otherwis } \\
\text { firm; } 0 \text { othe } \\
05 \text { and the } \mathrm{y} \\
\text { ar t-1 }\end{array}$ & vise & 0 otherwise & \\
\hline
\end{tabular}


TABLE 3

Ordered Logit Estimation of the Likelihood that ChuoAoyama Clients During the Period of Suspension: (i) Do not report an interim auditor, (ii) Switch to an interim auditor and then revert to Misuzu, or (iii) Switch to a final audit firm (do not revert back to Misuzu after suspension ends).

The dependent variable Switching takes the value of 0 if the firm does not have any interim auditor during the suspension, 1 if it adopts an interim auditor and goes back to Misuzu after the suspension ends, and 2 if it adopts a final auditor and does not revert to Misuzu. Column (1) excludes companies that move to Aarata as the final auditor after the suspension, whereas Column (2) includes companies that move to Aarata. All independent variables are measured for fiscal year 2005. Robust Z-stats are in parentheses. The column Odds Change presents the value of the change in odds for one standard deviation change in the value of the independent variable measured as $\exp (\mathrm{b} * \mathrm{SD}$ of $\mathrm{X})$, i.e. the change in odds for a one standard deviation increase in $\mathrm{X}$.

\begin{tabular}{|c|c|c|c|c|c|c|}
\hline \multirow[t]{2}{*}{ VARIABLES } & \multirow{2}{*}{$\frac{(1)}{\text { Coeff }}$} & \multicolumn{2}{|l|}{ No Aarata } & \multirow{2}{*}{$\begin{array}{l}\text { (2) } \\
\text { Coeff }\end{array}$} & \multicolumn{2}{|c|}{ Includes Aarata } \\
\hline & & z-stat & $\begin{array}{l}\text { Odds } \\
\text { Change }\end{array}$ & & z-stat & $\begin{array}{l}\text { Odds } \\
\text { Change }\end{array}$ \\
\hline Log Total Assets & 0.29 & $(2.00)^{* *}$ & 1.55 & 0.32 & $(2.53)^{* *}$ & 1.69 \\
\hline Std Dev Returns & 0.17 & $(0.82)$ & 1.13 & -0.01 & $(-0.04)$ & 0.99 \\
\hline Number of Segments & 0.15 & $(1.54)$ & 1.22 & 0.12 & $(1.35)$ & 1.17 \\
\hline Market-to-Book & 0.23 & $(2.20)^{* *}$ & 1.46 & 0.19 & $(2.13)^{* *}$ & 1.37 \\
\hline Leverage & -0.09 & $(-0.12)$ & 0.98 & -0.18 & $(-0.26)$ & 0.96 \\
\hline ROA & -0.01 & $(-0.17)$ & 0.97 & -0.01 & $(-0.28)$ & 0.97 \\
\hline Annual Returns & -0.00 & $(-0.43)$ & 0.95 & 0.00 & $(0.23)$ & 1.03 \\
\hline Foreign ownership & 0.01 & $(0.33)$ & 1.06 & 0.00 & $(0.04)$ & 1.00 \\
\hline Overseas sales ratio & -0.01 & $(-1.12)$ & 0.85 & -0.01 & $(-0.96)$ & 0.87 \\
\hline US Listing & 0.49 & $(0.95)$ & 1.12 & 0.42 & $(0.88)$ & 1.11 \\
\hline Keiretsu Inclination & 0.12 & $(1.25)$ & 1.16 & 0.07 & $(0.77)$ & 1.09 \\
\hline Owner Manager & -0.97 & $(-3.13) * * *$ & 0.63 & -0.73 & $(-2.55)^{* *}$ & 0.71 \\
\hline Industry Expert Auditor & 0.18 & $(0.25)$ & 1.10 & 0.53 & $(0.87)$ & 1.30 \\
\hline Abs Disc Accrual & 5.55 & $(1.80)^{*}$ & 1.23 & 3.74 & (1.27) & 1.14 \\
\hline$M \& A$ & 0.40 & $(1.54)$ & 1.20 & 0.24 & $(0.96)$ & 1.12 \\
\hline $\begin{array}{l}\text { Suspension } \\
\text { Announcement Return }\end{array}$ & -0.12 & $(-0.03)$ & 1.00 & -0.64 & $(-0.18)$ & 0.98 \\
\hline Firm Age & -0.00 & $(-0.66)$ & 0.91 & -0.00 & $(-0.25)$ & 0.96 \\
\hline Audit Fees & -0.41 & $(-0.76)$ & 0.90 & -0.50 & $(-0.94)$ & 0.87 \\
\hline Constant Cut 1 & 0.90 & $(0.70)$ & & 0.69 & $(0.58)$ & \\
\hline Constant Cut 2 & 3.43 & $(2.66)^{* * *}$ & & 2.92 & $(2.46)^{* *}$ & \\
\hline Industry Fixed Effects & Included & & & Included & & \\
\hline Observations & 386 & & & 433 & & \\
\hline Pseudo R-squared & 0.1155 & . & & 0.107 & & \\
\hline
\end{tabular}

$*, * *$, and $* * *$ represent significance at the 10\%, 5\%, and 1\% level respectively (two-sided tests). 
TABLE 4

The Relation between Audit Signatories at ChuoAoyama in Fiscal Year 2005 and Those at Subsequent Audit Firms in Fiscal Years 2006 and 2007

The table provides descriptive statistics on how many ChuoAoyama clients were audited in fiscal years 2006 or 2007 by the same audit partners in the successor audit firms as the audit partner who audited them in ChuoAoyama in fiscal year 2005. Audit partners are the signatories to the auditor report. For companies with multiple signatories, any one of the signatories being present in the next audit firm is counted as a common audit partner. The number of firms in panel A differs from that in panel B due to data availability, either because we do not find the relevant filing or because some firms delist between fiscal years 2006 and 2007.

Panel A: Continuation of At Least One Audit Partner from ChuoAoyama to the Successor Audit Firm between Fiscal Years 2006 and 2005

\begin{tabular}{|l|c|c|c|c|c|}
\hline & \multicolumn{5}{|c|}{ Same Partner in Next Audit Firm as in ChuoAoyama } \\
\hline $\begin{array}{l}\text { Successor } \\
\text { Audit Firm }\end{array}$ & $\begin{array}{c}\text { No Common Signatory } \\
\text { (\% of Total) }\end{array}$ & $\begin{array}{c}\text { At Least One Common } \\
\text { Signatory (\% of Total) }\end{array}$ & Total \\
\hline Aarata & 12 & $24 \%$ & 38 & $76 \%$ & 50 \\
\hline Azsa & 29 & $100 \%$ & 0 & $0 \%$ & 29 \\
\hline Misuzu & 42 & $15 \%$ & 239 & $85 \%$ & 281 \\
\hline Shin Nihon & 37 & $100 \%$ & 0 & $0 \%$ & 37 \\
\hline Tohmatsu & 23 & $100 \%$ & 0 & $0 \%$ & 23 \\
\hline Other Auditors & 19 & $100 \%$ & 0 & $0 \%$ & 19 \\
\hline Total & 162 & $37 \%$ & 277 & $63 \%$ & 439 \\
\hline
\end{tabular}

Panel B: Continuation of At Least One Audit Partner from ChuoAoyama to the Successor Audit Firm between Fiscal Years 2007 and 2005

\begin{tabular}{|l|c|c|c|c|c|}
\hline & \multicolumn{5}{|c|}{ Same Partner in Next Audit Firm as in ChuoAoyama } \\
\hline $\begin{array}{l}\text { Successor } \\
\text { Audit Firm }\end{array}$ & \multicolumn{2}{|c|}{$\begin{array}{c}\text { No Signatory in Common } \\
\text { (\% of Total) }\end{array}$} & $\begin{array}{c}\text { At Least One Common } \\
\text { Signatory (\% of Total) }\end{array}$ & Total \\
\hline Aarata & 25 & $46 \%$ & 29 & $54 \%$ & 54 \\
\hline Azsa & 53 & $65 \%$ & 29 & $35 \%$ & 82 \\
\hline Misuzu & 0 & $0 \%$ & 7 & $100 \%$ & 7 \\
\hline Shin Nihon & 77 & $47 \%$ & 88 & $53 \%$ & 165 \\
\hline Tohmatsu & 45 & $73 \%$ & 17 & $27 \%$ & 62 \\
\hline Other Auditors & 36 & $73 \%$ & 13 & $27 \%$ & 49 \\
\hline Total & 236 & $56 \%$ & 183 & $44 \%$ & 419 \\
\hline
\end{tabular}


TABLE 5

Market Reaction to Significant Events in the Kanebo/Chuo Aoyama Scandal

\section{Panel A: Descriptive Statistics of Returns of ChuoAoyama Clients on the Event Dates}

The table presents the mean and median market-adjusted returns for ChuoAoyama clients over the three-day window centered on the event dates tabulated in Appendix A. Market adjustment is done using TSE Index for the market index. All returns are in percent.

\begin{tabular}{lllll}
\hline & $\begin{array}{l}\text { Market-Adjusted Returns for ChuoAoyama Clients (in } \\
\text { Percentage) }\end{array}$ \\
Events & Mean (T-Statistic) & Median (Z-Statistic) \\
\hline Event 1 & 0.74 & $(4.44)^{* * *}$ & 0.30 & $(3.52)^{* * *}$ \\
Event 2 & -0.66 & $(-2.56)^{* *}$ & -0.85 & $(-6.30)^{* * *}$ \\
Event 3 & -0.18 & $(-1.56)$ & -0.04 & $(-1.57)$ \\
Event 4 & -0.42 & $(-2.36)^{* *}$ & -1.05 & $(-6.37)^{* * *}$ \\
Event 5 & 0.23 & $(1.69)^{*}$ & -0.12 & $(-0.55)$ \\
Event 6 & 0.06 & $(0.41)$ & -0.56 & $(-2.88)^{* * *}$ \\
Event 7 & -0.85 & $(-4.49)^{* * *}$ & -1.48 & $(-8.32)^{* * *}$ \\
Event 8 & 0.22 & $(1.18)$ & 0.21 & $(0.65)$ \\
Event 9 & -2.56 & $(-11.75)^{* * *}$ & -1.90 & $(-10.80)^{* * *}$ \\
Event 10 & -0.53 & $(-3.41)^{* * *}$ & -1.21 & $(-5.90)^{* * *}$ \\
Event 11 & -0.30 & $(-2.27)^{* *}$ & -0.22 & $(-2.18)^{* *}$ \\
\hline
\end{tabular}

$*, * *$, and $* * *$ indicate that the returns are significantly different from zero at the $10 \%, 5 \%$, and $1 \%$ levels of significance respectively. 


\section{TABLE 5 (continued)}

\section{Panel B: Event Study Analysis of Reactions to Events Related to Revelation of Fraud Using Schipper and Thompson (1983)} Methodology

The table presents the coefficients and t-statistics (in parentheses) of the following regression. The event dates are presented in Appendix A and the variable definitions and data sources in Appendix B. TSE Index returns are computed using the Tokyo Stock Price Index (TOPIX). The sample size of 798 comes from returns on all trading days between January 1, 2004 and March 31, 2007.

$$
\text { Return }_{\mathrm{t}}=\quad \alpha_{0}+\beta_{1} \text { Return }_{\mathrm{TSE} \text { INDEX }}+\theta_{\mathrm{k}} \text { Event }_{\mathrm{k}, \mathrm{t}}+\varepsilon_{\mathrm{t}}
$$

\begin{tabular}{|c|c|c|c|c|c|c|c|c|c|c|c|c|}
\hline Variable & Event 1 & Event 2 & Event 3 & Event 4 & Event 5 & Event 6 & Event 7 & Event 8 & Event 9 & $\begin{array}{l}\text { Event } \\
10\end{array}$ & Event 11 & $\begin{array}{l}\text { All } \\
\text { Events } \\
1-11 \\
\end{array}$ \\
\hline Constant & $\begin{array}{l}0.03^{*} \\
(1.69)\end{array}$ & $\begin{array}{l}0.03^{*} \\
(1.83)\end{array}$ & $\begin{array}{l}0.03^{*} \\
(1.80)\end{array}$ & $\begin{array}{l}0.03^{*} \\
(1.79)\end{array}$ & $\begin{array}{l}0.03^{*} \\
(1.75)\end{array}$ & $\begin{array}{l}0.03^{*} \\
(1.75)\end{array}$ & $\begin{array}{l}0.03^{*} \\
(1.82)\end{array}$ & $\begin{array}{l}0.03^{*} \\
(1.75)\end{array}$ & $\begin{array}{l}0.03 * * \\
(2.00)\end{array}$ & $\begin{array}{l}0.03^{*} \\
(1.79)\end{array}$ & $\begin{array}{l}0.03^{*} \\
(1.82)\end{array}$ & $\begin{array}{l}0.03 * * \\
(2.12)\end{array}$ \\
\hline TSE Index Returns & $\begin{array}{l}0.86 * * * \\
(58.43)\end{array}$ & $\begin{array}{l}0.87 * * * \\
(58.51)\end{array}$ & $\begin{array}{l}0.86 * * * \\
(58.39)\end{array}$ & $\begin{array}{l}0.87 * * * \\
(58.46)\end{array}$ & $\begin{array}{l}0.86 * * * \\
(58.45)\end{array}$ & $\begin{array}{l}0.86 * * * \\
(58.43)\end{array}$ & $\begin{array}{l}0.87 * * * \\
(58.47)\end{array}$ & $\begin{array}{l}0.86 * * * \\
(58.45)\end{array}$ & $\begin{array}{l}0.86 * * * \\
(58.80)\end{array}$ & $\begin{array}{l}0.87 * * * \\
(58.44)\end{array}$ & $\begin{array}{l}0.86 * * * \\
(58.35)\end{array}$ & $\begin{array}{l}0.87^{* * *} \\
(58.61)\end{array}$ \\
\hline Event i & $\begin{array}{l}0.31 \\
(1.26)\end{array}$ & $\begin{array}{l}-0.28 \\
(-1.12)\end{array}$ & $\begin{array}{l}-0.16 \\
(-0.63)\end{array}$ & $\begin{array}{l}-0.12 \\
(-0.49)\end{array}$ & $\begin{array}{l}0.05 \\
(0.18)\end{array}$ & $\begin{array}{l}0.06 \\
(0.25)\end{array}$ & $\begin{array}{l}-0.24 \\
(-0.95)\end{array}$ & $\begin{array}{l}0.03 \\
(0.11)\end{array}$ & $\begin{array}{l}-0.88 * * * \\
(-3.56)\end{array}$ & $\begin{array}{l}-0.13 \\
(-0.51)\end{array}$ & $\begin{array}{l}-0.22 \\
(-0.88)\end{array}$ & $\begin{array}{l}-0.15^{*} \\
(-1.94)\end{array}$ \\
\hline Observations & 798 & 798 & 798 & 798 & 798 & 798 & 798 & 798 & 798 & 798 & 798 & 798 \\
\hline Adjusted R2 & 0.81 & 0.81 & 0.81 & 0.81 & 0.81 & 0.81 & 0.81 & 0.81 & 0.81 & 0.81 & 0.81 & 0.81 \\
\hline
\end{tabular}

